\title{
Molecular characterization of the MuRF gene family: Potential role in rainbow trout muscle degradation
}

\author{
Jiannan Wang \\ West Virginia University
}

Follow this and additional works at: https://researchrepository.wvu.edu/etd

\section{Recommended Citation}

Wang, Jiannan, "Molecular characterization of the MuRF gene family: Potential role in rainbow trout muscle degradation" (2010). Graduate Theses, Dissertations, and Problem Reports. 3212.

https://researchrepository.wvu.edu/etd/3212

This Thesis is protected by copyright and/or related rights. It has been brought to you by the The Research Repository @ WVU with permission from the rights-holder(s). You are free to use this Thesis in any way that is permitted by the copyright and related rights legislation that applies to your use. For other uses you must obtain permission from the rights-holder(s) directly, unless additional rights are indicated by a Creative Commons license in the record and/ or on the work itself. This Thesis has been accepted for inclusion in WVU Graduate Theses, Dissertations, and Problem Reports collection by an authorized administrator of The Research Repository @ WVU. For more information, please contact researchrepository@mail.wvu.edu. 


\title{
Molecular characterization of the MuRF gene family: potential role in rainbow trout muscle degradation
}

\author{
Jiannan Wang
}

Thesis submitted to the Davis College of Agriculture, Natural Resources and Design at West Virginia University in Partial Fulfillment of the requirements for the degree of

\author{
Master of Science \\ In \\ Animal and Nutritional Sciences
}

Jianbo Yao, Ph.D., Chair

Mohamed Salem, Ph.D.

P. Brett Kenney, Ph.D.

Division of Animal and Nutritional Sciences

Morgantown, WV

2010

Key words: Muscle, Rainbow Trout, Muscle degradation, Muscle atrophy, Protein turnover, MuRF 


\title{
ABSTRACT \\ Molecular characterization of the MuRF gene family: potential role in rainbow trout muscle degradation
}

\author{
Jiannan Wang \\ As United States and world seafood demand increases, aquaculture production becomes
} more important. Limited knowledge of molecular regulation of muscle growth and flesh quality hinders genetic improvement of these important traits in fish. Our goal is to enhance muscle growth and fillet quantity in rainbow trout, Oncorhynchus mykiss. Muscle growth is determined primarily by rate of protein turnover. Unlike mammals, rapidly growing fish have reduced protein degradation rather than increased protein synthesis. Studies in mammals showed that muscle atrophy results from increased protein breakdown, and is associated with activation of the ubiquitin proteasome pathway including induction of the muscle-specific ubiquitin protein ligase, MuRF-1. Animals lacking MuRF-1 are resistant to muscle atrophy. In fish, little is known about the role of proteasome/MuRF pathway in muscle degradation. The objectives of this study were to: 1) clone and characterize MuRF genes in rainbow trout, and 2) determine expression of MuRF genes in association with starvation- and spawning-induced muscle atrophy in rainbow trout. We have identified full-length cDNA sequences for three MuRF genes (MuRF-1, MuRF-2, and MuRF-3). These genes encode proteins with typical MuRF structural domains, including a RING-finger, a B-box and a Leucine-rich coiled-coil domain. RT-PCR analysis showed that all three genes are predominantly expressed in muscle and heart tissues. Real time PCR analysis revealed that the expression of all MuRF genes is up-regulated in starvation- and spawninginduced muscle atrophy in rainbow trout. These results suggest an important role for the MuRF genes in fish muscle protein degradation. Further studies are warranted to assess the potential use of MURF genes as tools to monitor fish muscle growth and degradation. 


\section{ACKNOWLEDGEMENT}

I take this opportunity to sincerely give my heartfelt thanks and appreciation to my advisor, Dr Yao, for his constant support, patient tutorship. It has been a great privilege and joy to study under his guidance and encouragement.

Meanwhile special thanks also go to the advisory committee members, Dr Mohamed Salem gave me in-depth comment and invaluable advice in preparing my manuscript through the beginning to the end. And Dr. Brett Kenney helped me for the critical evaluation of my thesis.

Colleagues in the lab were always very helpful whenever I needed their support. I thank them all.

Faculty in the division were very cordial and supportive of me and I duly acknowledge them all. I all thank my fellow grad students in the division for their support and friendship. I would like to express my gratitude for their enlightening instruction and warm-hearted assistance.

It gives me great pleasure when I think of my friends in WVU. They were always there to listen to me whenever I needed and I thank them all.

Last but not least, many thanks go to my families for their sympathetic understanding and unfailingly support during my studies and during my preparation of my thesis. 


\section{TABLE OF CONTENTS}

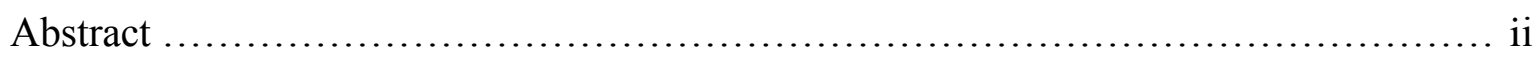

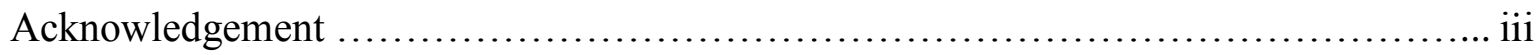

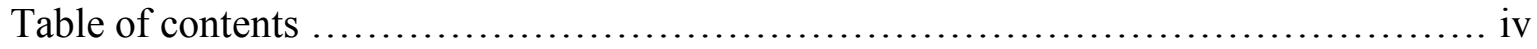

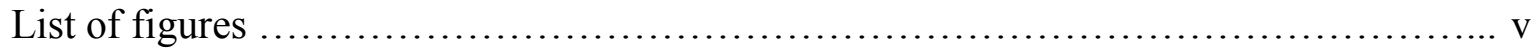

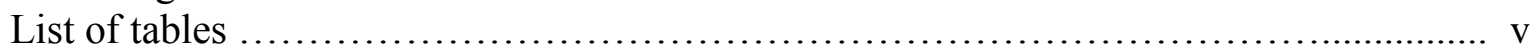

\section{REVIEW OF LITERATURE}

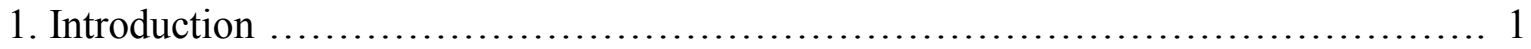

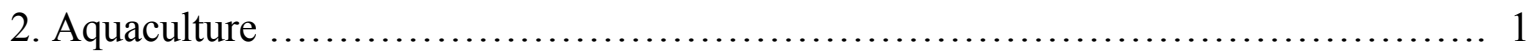

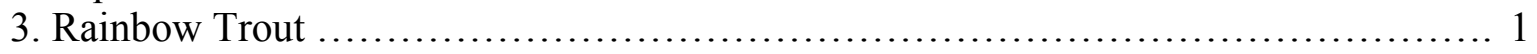

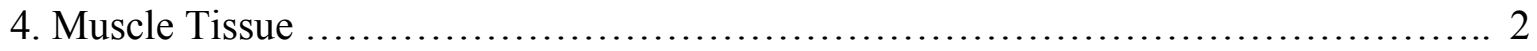

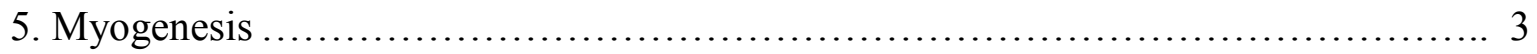

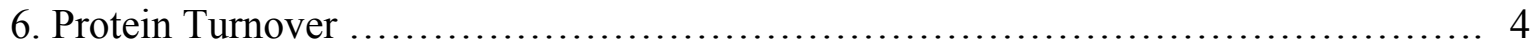

7. Protein Degradation and Proteolytic systems ................................. 5

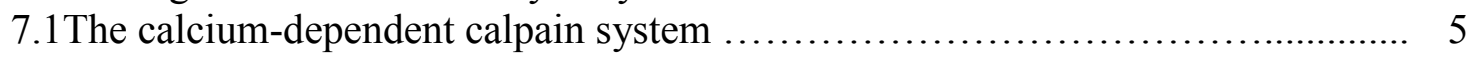

7.2The lysosomal protease system ........................................ 6

7.3The ATP-dependent ubiquitin-proteasome system ......................... 6

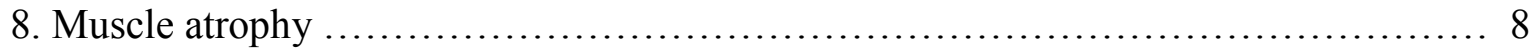

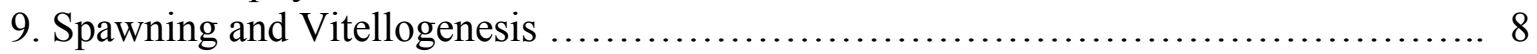

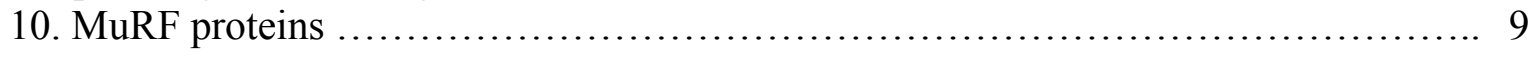

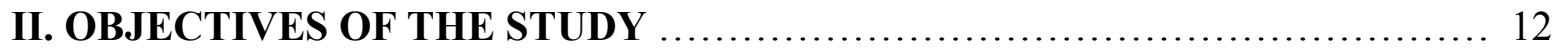

\section{MATERIALS AND METHODS}

1. Identification and of MuRF-1, MuRF-2 and MuRF-3 cDNA ..................... 13

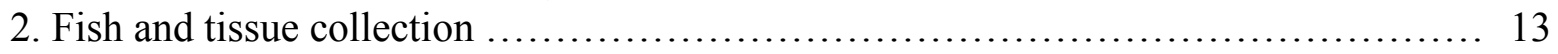

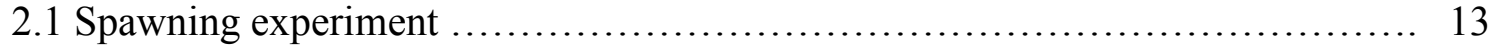

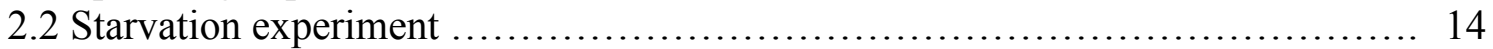

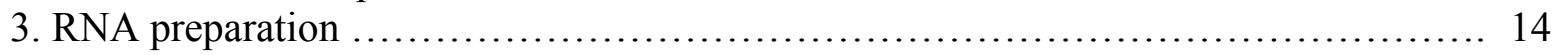

4. Reverse Transcription-Polymerase Chain Reaction .............................. 15

5. Preparation of DIG labeled anti-sense PCR probe ................................ 16

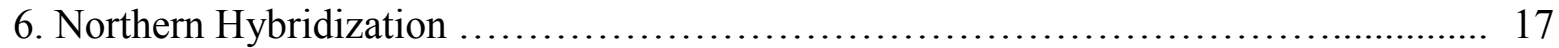

7. Quantitative Real Time PCR assay ............................................ 17

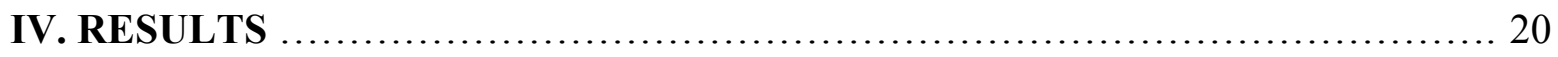

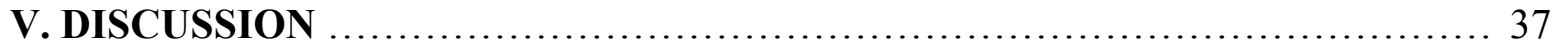

VI. LITERATURE CITED ....................................................... 43 


\section{LIST OF FIGURES}

Figure 1: MuRF molecules in mammals ................................... 10

Figure 2: Schematic diagram of the MuRF amino acid sequences $\ldots \ldots \ldots \ldots \ldots \ldots \ldots \ldots .25$

Figure 3: Comparison of rainbow trout MuRF-1 with other species $\ldots \ldots \ldots \ldots \ldots \ldots \ldots 26$

Figure 4: Comparison of rainbow trout MuRF-2 with other species $\ldots \ldots \ldots \ldots \ldots \ldots \ldots .27$

Figure 5: Comparison of rainbow trout MuRF-3 with other species ................. 28

Figure 6: Multiple alignment of three MuRF genes amino acid sequences ............. 29

Figure 7: RT-PCR analysis of tissue distribution of the rainbow trout

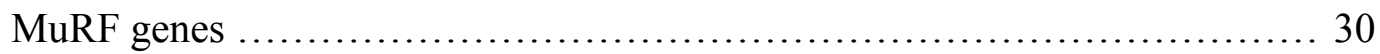

Figure 8: Northern blot expression analysis of three MuRF mRNA $\ldots \ldots \ldots \ldots \ldots \ldots \ldots . . \ldots 1$

Figure 9: Real time PCR analysis of MuRF-1 mRNA levels

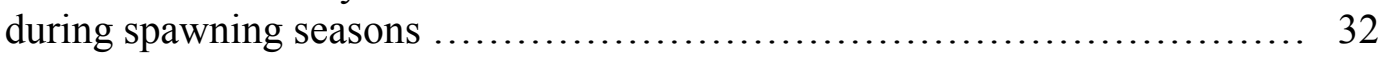

Figure 10: Real time PCR analysis of MuRF-2 mRNA levels

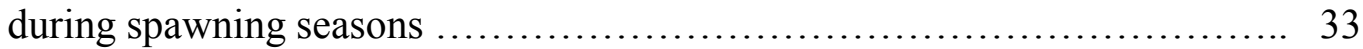

Figure 11: Real time PCR analysis of MuRF-3 mRNA levels during spawning seasons

Figure 12: Effect of spawning-induced muscle atrophy on three MuRF genes expression

Figure 13: Effect of spawning-induced muscle atrophy on three MuRF genes expression 36

Figure 14: Generalized annual gonadal cycle of freshwater fish 40

\section{LIST OF TABLES}

Table 1: PCR primers used in the study 


\section{REVIEW OF LITERATURE}

\section{Introduction}

Muscle is the only edible part and the largest protein reservoir in fish. Fish muscle is a highly desired source of protein, minerals and fatty acids. Fish muscle proteins are the primary reserve of amino acids that can be mobilized during fasting and disease to provide a source of amino acids for hepatic gluconeogenesis and energy production (Kettelhut, Wing et al. 1988). In aquaculture, muscle growth and fillet quality are important production traits. By developing molecular/genetic markers for monitoring and controlling muscle proteolysis, we can increase muscle protein accretion during fish growth and decrease postmortem protein degradation (less fillet softening).

\section{Aquaculture}

Aquaculture in the United States is a diverse industry that includes production of a variety of fish, shrimp, shellfish, and seaweeds. It is a relatively young industry. Aquaculture is the world's fastest growing agri-food business. Unprecedented growth in aquaculture production in the past decade has increased its importance to the modern food supply. The United States claims $20 \%$ of the world's marine fisheries resources, but it is still not enough for the demand. In terms of economic importance, a \$9 B seafood trade deficit was reported in 2009, the highest

drain on the US balance of payments next to oilk. As the US and world seafood demand increases, aquaculture becomes more and more important. In 1980, 9\% of the fish consumed (NAHMS 1995) came from aquaculture compared to $75 \%$ in 2009.

\section{Rainbow trout}


Rainbow trout (Oncorhynchus mykiss) is the most cultivated cold freshwater fish in the US. Rainbow trout is an important animal model for biomedical research (Thorgaard, Bailey et al. 2002). Between 1983 and 1992, the value of the trout industry represented 13 percent of the total estimated value of the aquaculture industry. The number of trout farms was 513 in 1982 and 577 in 1992. Trout farms are spread throughout the US, except they do not tend to be found in the southeast (Anonymous 1995). The need for cool/cold water temperatures throughout the year is the principal driving force in determining the industry's geographic distribution. It indicates that the trout industry is not balance for future abundant expansion due to some tendency combined of production of trout. The availability of cool and clean water is the major limitation to trout production. For example, producing a pound of fish require 5,000 to 10,000 gallons of water in a flow-through production system (Hopkins and Manci 1992). The United States Trout Farmer's Association is carrying out a quality insurance program that addresses decreasing production costs, improving management practices, and preventing drug and chemical pollution (Anonymous 1995).

\section{Muscle tissue}

Muscle tissue is one of the four basic tissues in animals. Muscle cells are contractile cells. Specialized proteins allow the cells to shorten. Their ability to contract provides a mechanism for movement of the internal organs and locomotion of the entire organism. Muscle tissue can be divided into 3 major types: skeletal, cardiac and smooth. Muscle tissue is controlled by nerves, hormones, local chemicals, or itself depending on type and location.

Skeletal muscle is under voluntary control, attaches to bones or fascia and constitutes the flesh of the limbs and body wall. Muscle cells (myofibers) are long, multinucleated, and arranged in parallel bundles. Unlike smooth and cardiac muscle, each skeletal myofiber is 
innervated by a neuron. Light microscopy reveals that cardiac and skeletal muscle cells contain transverse striations. For this reason, these muscle types are referred to as "striated." The striated appearance results from the presence of a highly organized network of actin and myosin protein filaments that convert chemical energy to mechanical energy in the form of muscle contraction.

Smooth muscle is not under voluntary control and comprises the walls of most of the viscera and blood vessels of the body. There is one centrally placed nucleus per cell. Unlike skeletal muscle, smooth muscle cells (myofibers) are not generally individually innervated. Instead, adjacent smooth myofibers may form junctions with one another that allow excitation and contraction to pass from one cell to another.

Cardiac muscle is involuntary, striated in appearance and contracts rhythmically and automatically. It is found only in the myocardium (the muscle layer of the heart). Each cell has a single, centrally located nucleus and joins end to end with other cardiac muscle cells at specialized junctional zones called intercalated discs. These junctions allow the action potential to pass from one fiber to another and harness the contraction of individual cells so that overall muscle shortening can occur.

\section{Myogenesis}

Muscle develops from mesodermal somites; some mesodermal stem cells must migrate from the somites to a location in the body where muscle development is needed. These precursor cells are determined or committed to a muscle cell lineage. Cells at this point are termed myoblasts, these cells are proliferative competent and may give rise to additional myoblasts. These cells receive the pertinent environmental signal to differentiate; at this point, the cells stop 
dividing and begin to align with one another. Cell membranes fuse together to form the myotube. Then, through the addition of more myofibrils, muscle fibers mature.

\section{Protein turnover}

Protein turnover is a balance between protein synthesis and degradation. More synthesis than breakdown indicates an anabolic state that builds lean tissues; more breakdown than synthesis indicates a catabolic state that burns lean tissues. All intracellular proteins and many extracellular proteins are continually "turning over" they are being hydrolyzed to their constituent amino acids and replaced by new molecules. Although the continual destruction of cell proteins might seem wasteful, this process serves several important homeostatic functions. Individual proteins in the nucleus and cytosol, as well as in the endoplasmic reticulum (ER) and mitochondria, are degraded at widely differing rates that vary from minutes for some regulatory enzymes to days or weeks for proteins such as actin and myosin in skeletal muscle or months for hemoglobin in the red cell. Cells contain (1) multiple proteolytic systems to carry out the degradation process and (2) complex regulatory mechanisms to certify the highly selective, continual proteolytic processes. Overall, rates of protein synthesis and degradation must be balanced precisely because even a small decrease in synthesis or a small acceleration of degradation, if sustained, can result in a marked loss of mass in the organism (Mitch 1996). Mature tissues remain in a state of balance between anabolic and catabolic pathways; whereas, growing tissues undergo cell hyperplasia or hypertrophy when anabolism exceeds catabolism. The efficiency with which an animal uses dietary protein is related to protein consumption and rate of protein turnover (Houlihan, Munder et al. 1995; Carter and Bransden 2001). In fish, it has been recognized that the rate of protein turnover plays an important role in determining growth 
of fish muscle. Fish turnover less protein per unit protein consumed, and convert more protein to growth than mammals (McCarthy, Casinghino et al. 1994). This difference may be the result of a lower metabolic rate of ectothermic animals.

Unlike mammals, fast efficiently growing fish have reduced protein degradation rather than increased protein synthesis. Therefore, detailed knowledge of protein degradation in fish will benefit fish muscle studies, and the aquaculture industry.

\section{Protein degradation and proteolytic systems}

Protein degradation in animal cells is a highly selective, regulated and energy dependent process that is controlled by activities of proteolytic enzymes (Hershko, Ciechanover et al. 2000). There are four known proteolytic systems involved in muscle protein degradation. These are (1) the calcium-dependent calpain system (Bartoli and Richard 2005; Costelli, Muscaritoli et al. 2005; Hasselgren, Menconi et al. 2005) (2) the lysosomal protease system (cathepsins) (Farges, Balcerzak et al. 2002; Busquets, Garcia-Martinez et al. 2006) (3) the ATP-dependent ubiquitin-proteasome system (Attaix, Ventadour et al. 2005; Cao, He et al. 2005; Tisdale 2005), and (4) apoptosis protease system(caspase) (Lee, Froelich et al. 2004; Leeuwenburgh, Gurley et al. 2005; Tews, Behrhof et al. 2005; Siu and Alway 2006).

\subsection{The calcium-dependent calpain system}

Calpains are cysteine proteases. When cells are injured and cytosolic calcium rises, calpains become active. Calpain-mediated proteolysis is involved in myofibrillar disassembly. It is the early rate-limiting step in myofibrillar protein degradation during muscle atrophy (Bartoli and Richard 2005; Costelli, Muscaritoli et al. 2005; Hasselgren, Menconi et al. 2005). 


\subsection{The lysosomal protease system}

Lysosomal proteases play a major role in degrading membrane-associated proteins during atrophy. Receptors, ligands, extracellular proteins and some cell surface proteins are taken up by endocytosis and degraded within lysosomes. These organelles contain several proteases including cathepsins (Farges, Balcerzak et al. 2002; Busquets, Garcia-Martinez et al. 2006).

\subsection{The ATP-dependent ubiquitin-proteasome system}

The ubiquitin-proteasome proteolytic pathway is a major route of muscle protein degradation. It involves two discrete steps: (1) ubiquitination, tagging of the substrate protein by the covalent attachment of multiple ubiquitin molecules (conjugation) and (2) proteasome degradation, the subsequent degradation of the tagged protein by the $26 \mathrm{~S}$ proteasome (Attaix, Ventadour et al. 2005; Cao, He et al. 2005; Tisdale 2005).

During ubiquitination, multiple ubiquitin molecules covalently attach to the protein substrate. Ubquitin is conjugated to proteins by an ATP-dependent process and involves three enzymes: E1 is Ub-activating enzyme, it activates ubiquitin and requires ATP as an energy source. E2 is Ub-carrier or conjugating proteins, its function is preparing $\mathrm{Ub}$ for conjugation. E3 is Ub-protein ligase. The last step is a rate-limiting step. E3 is the key enzyme responsible for targeting ubiquitination to specific substrate proteins and catalyzing the transfer of an activated $\mathrm{Ub}$ from a specific Ub-carrier protein (E2) to a lysine residue on the substrate (Attaix, Combaret et al. 2001; Pickart 2001).

Recent results suggest that Atrogin-1 (muscle atrophy F-box) and MuRF-1 (muscle RING finger 1) are two Ub-protein ligases (E3) that are key players in the regulation of ubiquitin-proteasome-mediated muscle atrophy in mammals (Bodine, Latres et al. 2001; Gomes, 
Lecker et al. 2001; Lecker, Jagoe et al. 2004). Additional ubiquitin molecules are attached to previously conjugated ubiquitin molecules to form a polyubiquitin chain. If the chain is longer than 3 ubiquitin molecules, the tagged protein is rapidly degraded by the 26S-proteasome into small peptides.

Proteasome degradation: Proteasomes are large protein complexes, containing a central core. During proteasome degradation, an ATP-dependent reaction, Ub is removed and the protein is linearized. Through the core, the linearized polyubiquitinated chain can enter the proteasome and then be degraded to peptides. Peptides are digested to amino acids by peptidases in the cytoplasm or used in antigen presentation. Because the size of the core is limited, some intact myofibrils cannot enter. Therefore, the ubiquitin-proteasome proteolytic system cannot degrade intact myofibrils. Albeit, the calpain system can degrade these structures.

The three proteolytic pathways sometimes work together. For example:

(1) The calpain system operates in conjunction with the ubiquitin-proteasome system in degrading myofibrillar protein.

(2) The lysosomal and ubiquitin-proteasome system work together to degrade specific protein substrates.

(3) A number of mammalian receptors and ion channels are ubiquitinated and then degraded by either lysosomal or proteasomal systems. If a protein is ubiquitinated by a polyubiquitin chain, it will be recognized and degraded by the proteasome. However, if the protein substrate is mono- or di-ubiquitinated, then it will be transported to a lysosome because it is not recognized by the proteasome (Lecker, Goldberg et al. 2006).

The various performances of these systems have been widely discussed (Millward 1985; Kumamoto, Fujimoto et al. 2000; Lecker, Jagoe et al. 2004) with strong evidence that the ATP- 
dependent ubiquitin-proteasome pathway is essential during the majority of protein degradation during muscle atrophy in mammals (Lecker, Solomon et al. 1999; Jagoe and Goldberg 2001). However, in fish, little is known about the proteolytic strategies of muscle protein degradation. Some studies suggested that the ubiquitin-proteasome pathway is not involved in vitellogenesisinduced atrophy (Salem, Kenney et al. 2006); this pathway is even down-regulated in fastinginduced fish muscle degradation (Martin, Blaney et al. 2002).

\section{Muscle atrophy}

Muscle atrophy is defined as a decrease in muscle mass; it can be a partial or complete wasting away of muscle. When a muscle atrophies, it becomes weaker, because the ability to exert force is related to mass. Muscle wasting and weakness are common in many disease states and conditions including aging, cancer cachexia, sepsis, denervation, disuse, inactivity, burns, HIV-acquired immunodeficiency syndrome (AIDS), chronic kidney or heart failure, unloading/microgravity, and muscular dystrophies (Lynch, Schertzer et al. 2007). Muscles maintain their mass and function because of a balance between protein synthesis and degradation associated with equal rates of anabolic and catabolic processes, respectively. Muscles grow when protein synthesis exceeds protein degradation. Conversely, muscles shrink when protein degradation dominates. Understanding pathways that regulate skeletal muscle mass

is crucial for development of successful nutritional or drug interventions that can attenuate wasting and weakness and improve muscle structure and function.

\section{Spawning and vitellogenesis}


The natural habitat of the rainbow trout is the cool waters of the Northern Hemisphere. Nonetheless, trout have been introduced throughout the world and this specie is now widely acclimatized. With fast growth, rainbow trout reach sexual maturity earlier than other trout strains. Rainbow trout may spawn first when they reach about 12- 16 inches in length, which is usually at the end of their second year (Roberts, Lowery et al. 1988). Trout spawn in spring or autumn. Most trout spawn in streams, rivers, and lakes with gravel bottoms and steady water flow. Vitellogenesis, also known as yolk deposition, is the process of yolk formation via nutrients being deposited in the oocyte, the female germ cell. It entails the synthesis of vitellogenin by the liver and its uptake by growing oocytes, where it is stored as yolk to serve as the food reserve of the developing embryos. Rainbow trout, during vitellogenesis, face substantial energetic challenge that results in a significant loss of muscle mass and mobilization of a substantial amount of muscle proteins likely to support accumulation of large amounts of yolk in developing ova. Albeit, the impact on farmed fish is determined by the nutritional status of the female at spawning. Previous work in our lab reported an $11 \%$ reduction in the separable muscle mass for fertile fish during spawning compared to sterile fish and fertile post spawning fish (Salem, Kenney et al. 2006). In addition, the concentration of muscle proteins in fertile spawning fish decreased 11\% (Salem, Kenney et al. 2006). The reduction in muscle protein is coupled with an increase in muscle water content (Salem, Kenney et al. 2006).

\section{MuRF proteins}

Muscle-specific RING-finger (MuRF) proteins are expressed specifically in cardiac and skeletal muscle. MuRF belongs to the RING-B-box-coiled-coil (RBCC) subclass of RING-finger proteins, characterized by an NH2-terminal RING-finger followed by a zinc-finger domain (B- 
box) and a leucine-rich coiled-coil domain. The structure is shown in figure (Spencer, Eliazer et al. 2000).

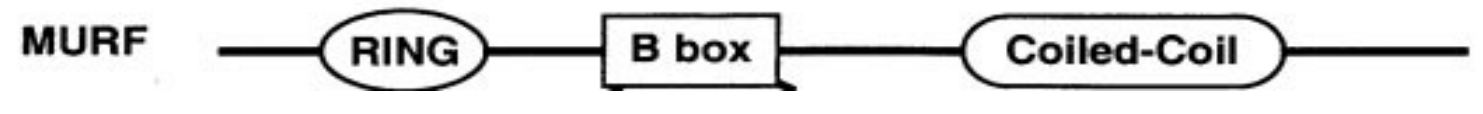

Figure 1: MuRF molecules in mammals (Spencer, Eliazer et al. 2000).

The RING-finger domain is an unusual type of Cys-His zinc-binding motif found in a growing number of proteins with roles in signal transduction, gene transcription, differentiation, E2-dependent ubiquitination, and morphogenesis (Saurin, Borden et al. 1996; Borden 1998; Freemont 2000). The functions of the MuRF genes have been widely discussed in mammals. Expression of MURF3 is required for skeletal myoblast differentiation and myotube fusion. In addition, MuRF3 can act as a myogenic regulator of the muscle microtubule network and is required for myogenesis (Spencer, Eliazer et al. 2000). Mice lacking MuRF-3 display normal cardiac function but are prone to cardiac rupture after acute myocardial infarction, which indicate that MuRF-3 is important in maintaining cardiac integrity and function after acute myocardial infarction (Fielitz, van Rooij et al. 2007). MuRF-1 and MuRF-2 play significant roles in signal transduction and transcriptional regulation during muscle atrophy. MuRF-1 is ubiquitin ligase and the only MuRF family member that is expressed throughout development. MuRF-1 is highly expressed in response to multiple stimuli of muscle atrophy. Deletion of MuRF-1 in mice inhibits skeletal muscle atrophy (Bodine, Latres et al. 2001). MuRF-1 is able to bind the transcription factor, glucocorticoid modulatory element binding protein-1 (McElhinny, Kakinuma et al. 2002), with subsequent modulation of glucocorticoid-responsive gene 
transcription. The role of the MuRF atrogin family seems to be evolutionarily conserved and consistent, suggesting an essential function in modulating muscle degeneration. MuRF proteins can be used as biomarkers for monitoring muscle atrophy. MuRF-1 interacts with the myofibrillar giant spring protein, titin, at the M-line, resulting in disruption of the subdomain of titin that binds MuRF-1. MuRF-1 is ubiquitin ligase that degrades cardiac troponin-1 in a proteasome-dependent manner (Kedar, McDonough et al. 2004). MuRF-2 may link together the functions of the myofibrillar-based MuRF-1 and microtubular-based MuRF-3. MuRF-2, important for microtubule, intermediate filament and sarcomeric M-line maintenance, is a regulator of myocardiocytic contractility (McElhinny, Kakinuma et al. 2002). Microarray gene expression analysis showed that MuRF-3 is up-regulated in atrophying rainbow trout muscle, suggesting a role of this gene in fish muscle protein degradation (Salem, Kenney et al. 2006). 


\section{OBJECTIVES OF THE STUDY}

Due to problems of over-fishing, pollution and destruction of marine and freshwater fisheries, aquaculture is an approach for production of aquatic food to meet an increasing U.S demand. Genetically improved strains of food fish are requisite for production efficiency in a profitable aquaculture industry. In food fish, there is limited genetic information on traits that enhance production of a high quality muscle. The ultimate goal of this study is to identify molecular/genetic markers for monitoring and controlling muscle proteolysis to increase muscle/fish protein accretion during fish growth and to decrease postmortem degradation that cause fillet softening. MuRF proteins, the important members (E3 Ub-protein ligases) of the Ubiquitin-proteasome pathway, are involved in mammalian muscle degradation. Animals lacking MuRF-1 are resistant to muscle atrophy. In fish, little is known about the role of proteasome/MuRF genes in muscle degradation. We believe that MuRF genes may play a critical role in fish muscle atrophy. During spawning, muscle atrophy is a physiological response to increased energetic demands. Additionally, starvation induces atrophy in muscle. These responses suggest that spawning and starvation represent suitable models to study mechanisms of muscle degradation/regeneration in fish. The objectives of this study were to: 1) clone and characterize MuRF genes in rainbow trout, and 2) determine expression of MuRF genes in association with starvation- and spawning-induced muscle atrophy in rainbow trout. 


\section{MATERIALS AND METHODS}

\section{Identification and of MuRF-1, MuRF-2 and MuRF-3 cDNAs}

Nucleotide and amino acid sequence homology, searched against the GenBank database (http://www.ncbi.nlm.nih.gov/), were used to examine rainbow trout (Oncorhynchus mykiss) expressed sequence tags to identify MuRF-like clones. We identified and sequenced three rainbow trout cDNA clones (GenBank accession No.: CA369980, CA342294, BX321103) that had high homology with mammalian MuRFs. Clones were obtained from USDA NCCCWA (Kearneysville, WV). All clones were completely sequenced and aligned to generate the full length sequences for rainbow trout MuRF-1, MuRF-2 and MuRF-3, respectively. CLOSTALW version 1.81 (http:www.cmbi.kun.nl/cgi-bin) algorithm was used for protein multiple alignments. The characteristic domains of three MuRF proteins were assigned by blasting their sequences against the Protein Families Database of Alignment_Pfam, http://www.sanger.ac.uk/Software/ $\underline{\text { Pfam/search.shtml) }}$ and according to references (Spencer, Eliazer et al. 2000).

\section{Fish and tissue collection}

\subsection{Spawning experiment}

Fertile (diploid, 2N) and sterile (triploid, 3N) rainbow trout females (Oncorhynchus. mykiss) were obtained from the National Center for Cool and Cold Water Aquaculture (Kearneysville, WV, USA). Triploid fish were produced by preventing meiosis after fertilization using hydrostatic pressure. Fish were weighed and length was measured (tip to tail fork) once a month between July 2008 and March 2009. Ten fish per treatment ( $2 \mathrm{~N}$ and $3 \mathrm{~N}$ from each family) were randomly sampled in July, September, November, December, January, and March (6 periods). Fish were held off feed $24 \mathrm{hrs}$ prior to sampling and were anesthetized using Tricaine 
Methanesulfonate (MS222) at NCCCWA. Total body weight, eviscerated body weight (or headon gutted weight), viscera weight, liver weight, heart weight, and gonad weight were recorded. Evisceration and filleting were performed manually. White muscle samples and some other tissues were frozen in liquid nitrogen and stored at $-80{ }^{\circ} \mathrm{C}$ until further processing. Portions of the frozen muscle tissues were used for RNA isolation for further experiments.

\subsection{Starvation experiment}

Samples used in this study were previously described (Salem, Yao et al. 2005). Rainbow trout fingerlings (15-20 g) were brought from Bowden State Fish Hatchery, WV Division of Natural Resources (Elkins, WV) to the laboratory and acclimatized for 30 days. Temperature $\left(14.0^{\circ} \mathrm{C} \pm 1\right)$, dissolved oxygen, $\mathrm{pH}$, and other water quality parameters were kept constant throughout the study. Fish were randomly divided into six experimental groups (60 fish each). Each group was assigned to a net pen $(60 \times 60 \times 60 \mathrm{~cm})$. To ensure that all fish receive uniform water quality, all pens were kept in the same aquaria $(1100 \mathrm{~L})$. Three control groups were manually fed a commercial fish diet (Zeigler Bros., Gardeners, PA) at $1 \%$ of fish body weight twice per day. Three experimental groups were subjected to a starvation regimen for 35 days. This starvation regimen was chosen based on the study of (Tripathi and Verma 2003)who showed that the maximum effect of fasting on Rainbow trout muscle protein content occurs after 35 days of starvation. At the end of the experimental period, nine fish from each experimental group were randomly sampled. Fish were euthanized and weighed, and white muscle samples were collected.

\section{RNA preparation}


Total RNA were isolated from afore mentioned samples (spawning fish muscle samples, starved and normal fed fish muscle samples, various tissues samples from one fish) using Trizol reagent (Invitrogen, Carlsbad, CA) following the manufacturer's protocol. Frozen tissue $(0.2 \mathrm{~g})$ was placed in $2 \mathrm{ml}$ of Trizol reagent and homogenized using a Polytron homogenizer. Messenger RNA was isolated from total RNA by using polyAtract mRNA isolation system (Promega, Madison, WI). Biotinylated oligo d(T) probe and streptavidin attached magnetic beads were used for this purpose. Total RNA and the resultant mRNA were stored at $-80{ }^{\circ} \mathrm{C}$ until use.

\section{Reverse transcription-polymerase chain reaction (RT-PCR)}

Treatment of RNA sample with DNase: Ten micrograms of total RNA, $3 \mu \mathrm{l}$ of $10 \mathrm{X}$ DNase I buffer and $1 \mu \mathrm{l}$ of DNase I (Ambion, Austin, TX) were added to a microcentrifuge tube and the volume was brought to $30 \mu \mathrm{l}$. This mixture was gently mixed and incubated at $37^{\circ} \mathrm{C}$ for 25 minutes. Five microliters of resuspended DNase Inactivation Reagent (DIR) were added and mixed well. After incubating for 2 minutes at room temperature, mixing occasionally, the sample was centrifuged at $12,000 \mathrm{rpm}$ for 1.5 minutes and the supernatant RNA was transferred to a fresh tube. The treated RNA was kept on ice.

First-strand cDNA synthesis: Two microliters of Oligo $(\mathrm{dT})_{18}(500 \mu \mathrm{g} / \mathrm{ml})$ and $2 \mu \mathrm{l}$ of dNTP mix (10 mM each) were added to $22 \mu \mathrm{l}$ of DNase treated RNA and incubated at $65^{\circ} \mathrm{C}$. After incubating for 5 minutes, $8 \mu 1$ of $5 \mathrm{X}$ first strand cDNA synthesis buffer, $4 \mu 1$ of $0.1 \mathrm{M}$ DTT and $2 \mu 1$ of SuperScript III RT (200U/ $\mu$ l, Invitrogen, Carlsbad, CA) were added. Contents in the tube were mixed gently by pipetting, and this mixture was incubated in a Thermocycler at $42^{\circ} \mathrm{C}$. After incubating for 50 minutes, the reaction was inactivated by heating at $70^{\circ} \mathrm{C}$ for 10 minutes 
in a Thermocycler. The RT product was diluted by adding $160 \mu 1$ of water. The mixture was stored at $-20^{\circ} \mathrm{C}$ until use.

Polymerase chain reaction: Twenty-five $\mu \mathrm{l}$ of the PCR reaction mixture $(3.75 \mu 1$ of PCR mixture containing dNTPs and buffer, $0.25 \mu \mathrm{l}$ of Taq polymerase (Invitrogen, Carlsbad, CA), $1.25 \mu \mathrm{l}$ of each primer, $5 \mu \mathrm{l}$ of cDNA and $13.5 \mu \mathrm{l}$ of water) was set up with the three MuRF gene specific primers, and PCR was performed for 35 cycles with each cycle consisting of $94^{\circ} \mathrm{C}$ for 30 seconds, annealing at $58^{\circ} \mathrm{C}$ for 45 seconds, extension at $72^{\circ} \mathrm{C}$ for 30 seconds and then incubated at $72^{\circ} \mathrm{C}$ for additional 10 minutes and was maintained at $4^{\circ} \mathrm{C}$. The amplified product was electrophoresed through a 1\% agarose gel along with a $100 \mathrm{bp}$ DNA ladder to estimate the size of the gene amplified. RT-PCR was done using cDNA from different tissues (spleen, kidney, white muscle, liver, gill, heart, brain, skin, testis and egg) to check the expression of the three MuRF genes. $\beta$-actin, a house keeping gene, was used as the control for all tissues, and PCR was performed under conditions similar as MuRF genes. Primers used in the PCR reactions are listed in (Table 1).

\section{Preparation of DIG labeled PCR probe}

DIG-labeled PCR probes, used for Northern blot analysis, were synthesized using a DIG PCR labeling kit (Roche Diagnostics, Indianapolis, IN). DIG labeled DNA fragments of rainbow trout MuRF-1 (427bp), MuRF-2 (564bp) and MuRF-3 (533bp) were synthesized by PCR using the corresponding cDNA clones as templates. In a sterile reaction tube, the following components were added : $5 \mu$ PCR buffer with $\mathrm{MgCl}_{2}$ (10xconc.), $5 \mu$ l PCR DIG Probe Synthesis Mix, $5 \mu$ each of forward and reverse gene specific primers, 0.75 Enzyme mix, $15 \mu \mathrm{g}$ template plasmid cDNA. The reaction volumn was brought to $50 \mu$ with water. PCR was 
performed for 30 reaction cycles; each cycle consisted of $94^{\circ} \mathrm{C}$ for 30 seconds, annealing at $58^{\circ} \mathrm{C}$ for 45 seconds, extension at $72^{\circ} \mathrm{C}$ for 30 seconds and then incubated at $72^{\circ} \mathrm{C}$ for an additional 10 minutes and was stored at $4^{\circ} \mathrm{C}$. The product was electrophoresed through a $1 \%$ agarose gel along with a $1 \mathrm{~kb}$ DNA ladder to check the probe size.

\section{Northern hybridization}

Five $\mu \mathrm{g}$ of muscle tissue mRNA, was separated on a $1 \%$ denaturing agarose gel by electrophoresis along with RNA marker (Promega, Madison, WI). Messenger RNA was subsequently transferred to an Hybond $\mathrm{N}+$ nylon membrane (Amersham Biosciences, Piscataway, NJ). The mRNA was cross linked onto the membrane by UV rays and then the membrane was pre-hybridized in DIG Easy Hyb solution (Roche Diagnostics, Indianapolis, IN) for 1 hour and then hybridized in the same solution containing DIG-labeled PCR probe $(2 \mu \mathrm{l} / \mathrm{ml}$ hybridization solution) overnight at $68^{\circ} \mathrm{C}$. Following stringent washes ( $4 \mathrm{x} 10$ min with $2 \mathrm{X}$ SSC, $0.1 \%$ SDS at room temperature and $4 \times 10$ min with $0.1 \mathrm{X}$ SSC, $0.1 \%$ SDS at $68^{\circ} \mathrm{C}$ ), the membrane was incubated in the blocking solution for 30 min followed by additional incubation with a blocking solution that contained a 1:10,000 dilution of alkaline phosphatase conjugated anti-DIG antibody (Roche Diagnostics, Indianapolis, IN). The second incubation was for 1 hour at room temperature. After 2 washes in wash buffer, the hybridized probe was detected with the chemilumisescent substrate CSPD (Roche Diagnostics, Indianapolis, IN). Blocking solution and washing solution were from a DIG wash and block buffer set (Roche Diagnostics, Indianapolis, $\mathrm{IN})$.

\section{Quantitative real-time PCR assay}


The expression of three MuRF genes, as affected by spawning and starvation, were measured using quantitative real-time PCR. Prior to reverse transcription, total RNA was treated with DNase I (Ambion, Austin, TX) to eliminate any possible genomic DNA contamination. Twenty-two microliters of DNAse-treated total RNA from each sample was converted to cDNA using Superscript III reverse transcriptase (Invitrogen, Carlsbad, CA). Real-time PCR primers (Table 1) for MuRF-1, MuRF-2 and MuRF-3 genes and the endogenous control gene, $\beta$-actin gene, were designed based on the corresponding cDNA sequences (rainbow trout $\beta$-actin gene: GenBank accession No.:AJ438158) using Primer3 software (http://frodo. wi.mit.edu/cgibin/primer3/primer3_www.cgi).

Quantitative PCR was performed in duplicate for each cDNA sample on a Bio-Rad iCycler iQ Real-Time PCR Detection System (Bio-Rad, Hercules, CA). iQiSYBR Green

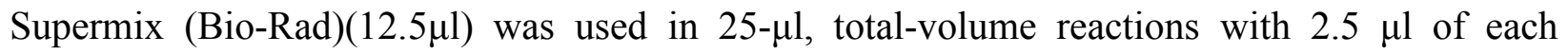
primer, $2.5 \mu \mathrm{l}$ of water and $5 \mu \mathrm{l}$ cDNA (1:5 dilution). Reaction mixtures $(25 \mu \mathrm{l})$ were preincubated 15 min at $95^{\circ} \mathrm{C}$ to activate the HotStart Taq DNA polymerase; samples were then amplified through 40 cycles with each cycle consisting of denaturation at $94{ }^{\circ} \mathrm{C}$ for $30 \mathrm{~s}$, annealing at $56{ }^{\circ} \mathrm{C}$ for $30 \mathrm{~s}$ and extension at $72{ }^{\circ} \mathrm{C}$ for $30 \mathrm{~s}$.

Trout $\beta$-actin gene was used as an endogenous control for normalization. Standard curves for the target genes and the reference gene were constructed using 10-fold serial dilutions of the corresponding plasmids. Standard curves were run on the same plate with the samples. Threshold lines were adjusted to intersect amplification lines in the linear portion of the amplification curve and cycles to threshold $(\mathrm{Ct})$ were recorded. For each sample, the amount of the target gene and endogenous reference were determined from the appropriate standard curve. The amount of the 
target gene was then divided by the amount of the reference gene to obtain a normalized target value. The mean differences in expression levels were determined by an ANOVA test or a t-test. 


\section{RESULTS}

\section{Identification and characterization of MuRF cDNA sequences}

By searching the rainbow trout EST database, we identified 3 rainbow trout MuRF genes. The cDNA clones for these genes (GenBank accession No: CA369980, CA342294, BX321103) were obtained from the NCCCWA (Kearneysville, WV, USA). The complete sequences of the cDNA clones were determined by primer walking. The predicted protein sequences were used to compare with known mammalian MuRF proteins for annotation. Clones CA369980, CA342294 and BX321103 were identified as rainbow trout MuRF-1, MuRF-2 and MuRF-3, respectively.

\subsection{MuRF1}

First, primers T7 and Sp6 were used to sequence the CA369980 clone from both ends. Additional primers (1RT20-5-1 and 1RT20-5-2; Table 1) were designed to extend the sequence from 5' to 3' end. The complete nucleotide sequence of MuRF-1 cDNA is $1791 \mathrm{bp}$ in length and contains an open reading frame encoding a protein of 359 amino acids (Fig. 2). The predicted protein sequence contains a RING-finger, a B-box and a Leucine-rich coiled-coil domain which are evolutionarily conserved. The protein is most closely related to the previously reported MuRF-1 in other species (Fig. 3). The amino acid sequence shows 67\% similarity with salmon MuRF-1 and 54\% with mouse MuRF-1.

\subsection{MuRF2}

Vector primers $\mathrm{T} 7$ and Sp6 were used in the first sequencing reaction to determine the CA342294 cDNA sequence from both ends. New primers (1RT27-5-1 and 1RT27-5-2) were designed to further sequence from the 5 , end and obtain the complete cDNA sequence. The 
cDNA sequence for MuRF2 is 2193 bp long and it codes for a protein of 490 amino acids (Fig. 2). The deduced amino acid sequence also contains a RING-finger, a B-box and a Leucine-rich coiled-coil domain and is closely related to the known MuRF-2 from other species as it shares $59 \%$ sequence identity with zebrafish and 66\% with mouse MuRF2 (Fig. 4).

\subsection{MuRF3}

First, vector primers T7 and T3 were used to sequence the BX321103 clone. Additional 5' and 3' end primers were designed to extend the sequence from both directions. The nucleotide sequence of MuRF-3 consists of 1785 bp, and it has an open reading frame coding for 350 amino

acids (Fig. 2). The deduced amino acid sequence displays high sequence homology with previously reported MuRF-3 in other species, with $85 \%$ identity to zebrafish and $53 \%$ to mouse (Fig. 5).

A schematic diagram comparing the sequences and domain structures of the rainbow trout MuRF proteins is shown in Fig. 2. Amino acid sequence analysis (Fig. 6) of MuRF1, MuRF2 and MuRF3 revealed all three MuRFs contain a RING-finger domain, a B-box zinc finger domain and a Leucine-rich coiled-coil domain. Each domain contains the highly conserved sequence motif that is essential for MuRF activity. The RING-finger domain is located at N-terminus, which is functional in protein-protein interaction. The C3HC4 type Zinc Finger in this domain is shown in Fig.4. Trout MuRF1 and MuRF2 share 49\% protein sequence identity, MuRF1 and MuRF3 share 67\% protein sequence identity, MuRF2 and MuRF3 share $57 \%$ protein sequence identity.

\section{Tissue distribution of rainbow trout MuRF genes}


The tissue distribution patterns of MuRF-1, MuRF-2 and MuRF-3 transcripts were determined by RT-PCR analysis (Fig. 7). Rainbow trout tissues including spleen, kidney, white muscle, liver, gill, heart, brain, skin, testis and egg were selected for analysis of MuRF gene expression patterns. MuRF-1 appears to be muscle specific as it was only expressed in muscle and heart but not in other tissues. Greater amounts MuRF-2 were detected in muscle and heart, but lesser amounts were present in brain and limited amounts in skin. MuRF-3 was abundantly in muscle and heart, but a weak expression was seen in spleen, liver and gill (Fig. 7).

\section{Northern blot analysis}

Nothern blot analysis, using mRNA isolated from either muscle or heart, revealed a single transcript of $1.9 \mathrm{~kb}$ for MuRF-1, 2 transcripts of $2.0 \mathrm{~kb}$ and $2.3 \mathrm{~kb}$ for MuRF-2 and a single transcript of $1.9 \mathrm{~kb}$ for MuRF-3 (Fig.8). The size of each transcript is consistent with the expected size of the corresponding cDNA size (MuRF-1, 1791 bp; MuRF-2, 2193 bp; MuRF-3, $1785 \mathrm{bp}$ ). The additional transcript of $2.0 \mathrm{~kb}$ for MuRF-2 detected by the MuRf-2 probe may represent an alternative splice variant.

\section{Real time PCR quantification of MuRF gene expression in spawning-induced and starvation-induced muscle atrophies}

To investigate the mRNA expression of MuRF genes during spawning-induced muscle atrophy in rainbow trout, fertile $(2 \mathrm{~N})$ and sterile $(3 \mathrm{~N})$ fish muscle samples were collected at six time points spawning sexual maturation and the spawning season; these samples were subjected to quantitative real-time PCR analysis. All three MuRF genes showed low and steady expression in the pre-spawning season (July, Sep and Nov) in $2 \mathrm{~N}$ and $3 \mathrm{~N}$ samples (Fig. 9, 10, 11). The three 
MuRF genes in $2 \mathrm{~N}$ fishes showed a significant $(\mathrm{P}<0.05)$ increase in expression in Dec, the month proceeding the spawning time (Fig. 12), with a subsequent decrease in Jan and Mar.

Comparison of MuRF gene expression between starvation and normal conditions is shown in Fig. 13. Clearly, all three MuRF transcripts showed up-regulated expression in starved fish muscle compared to normal fed fish muscle. A 7.1-fold increase in mRNA abundance for MuRF-1, 1.5-fold increase for MuRF-2 and 2.8-fold increase for MuRF-3 $(\mathrm{P}<0.05)$ were observed in fish that have had food withdrawn for 35 days compared to fed controls (Fig. 13). Both spawning induced and starvation induced muscle atrophies resulted in increased expression of the MuRF genes. 
Table1: Sequences of the PCR primers.

\begin{tabular}{|c|c|c|}
\hline Gene name & Primer sequence & Method \\
\hline MuRF1-5-1 & sense: AACGCCATAGATCTCCTTGCG & Primer walking \\
\hline MuRF1-5-2 & sense: CATCTTGTACCAAATGGGCTT & Primer walking \\
\hline MuRF1 & sense: CAAGAGCATCGAGGAGAACAG & Standard RT-PCR \\
\hline MuRF1 & $\begin{array}{l}\text { antisense: TCCTCTGTCACCACATCATCA } \\
\text { sense: CTGATTAGTGGCAAGGAGCTG } \\
\text { antisense: GTAAGGTGCTCCATGTTCTCG }\end{array}$ & Real time PCR \\
\hline MuRF2-5-1 & sense: CGATCACCTTTATGCCGTCCT & Primer walking \\
\hline MuRF2-5-2 & sense: GGCTGAACAACCAGAAGTAGA & Primer walking \\
\hline MuRF2 & $\begin{array}{l}\text { sense: AGGCACTAACATCTCCCACCT } \\
\text { antisense: AGCCAAGAAAAGGAGAAGACG }\end{array}$ & Standard RT-PCR \\
\hline MuRF2 & $\begin{array}{l}\text { sense: TGGAGGAGTCAGAGATGGCTA } \\
\text { antisense: TCCAGGTGGGAGATGTTAGTG }\end{array}$ & Real time PCR \\
\hline MuRF3 & sense: TTCAACCTGAATGTCCATTGC & Primer walking \\
\hline MuRF3-R1 & antisense: AAAGTCAATCCACTCCTTACG & Primer walking \\
\hline MuRF3-R2 & antisense: CGTAGAGCAGGTCGAAGCGCT & Primer walking \\
\hline MuRF3 & $\begin{array}{l}\text { sense: GATGGACTTTGGAATGGTCG } \\
\text { antisense: GCACGCAATCAATTCAAGCA }\end{array}$ & Standard RT-PCR \\
\hline MuRF3 & $\begin{array}{l}\text { sense: ATGTCCATTGCAGGGACTCTA } \\
\text { antisense: AACTGGGGTAAGCCATTGTGT }\end{array}$ & Real time PCR \\
\hline$\beta$-actin & $\begin{array}{l}\text { sense: GCCGGCCGCGACCTCACAGACTAC } \\
\text { antisense: GGCCGTGGTGGTGAAGCTGTAAC }\end{array}$ & Real time PCR \\
\hline
\end{tabular}




\section{MuRF1}

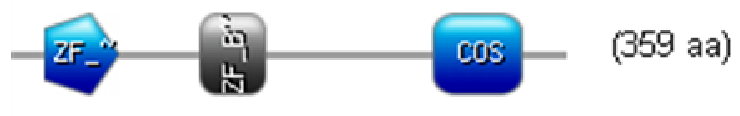

MuRF2

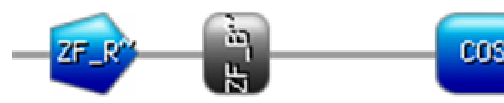

MuRF3

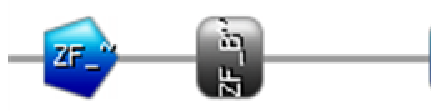

CoS

(350 aa)

Figure 2: Schematic diagram of the amino acid sequences of rainbow trout MuRF proteins showing conserved domain structures (RING-finger domain, B-box zinc finger domain and Leucine-rich coiled-coil domain). The rainbow trout MuRF-1, MuRF-2 and MuRF-3 proteins contain 359 aa, 490 aa and 350 aa, respectively. 


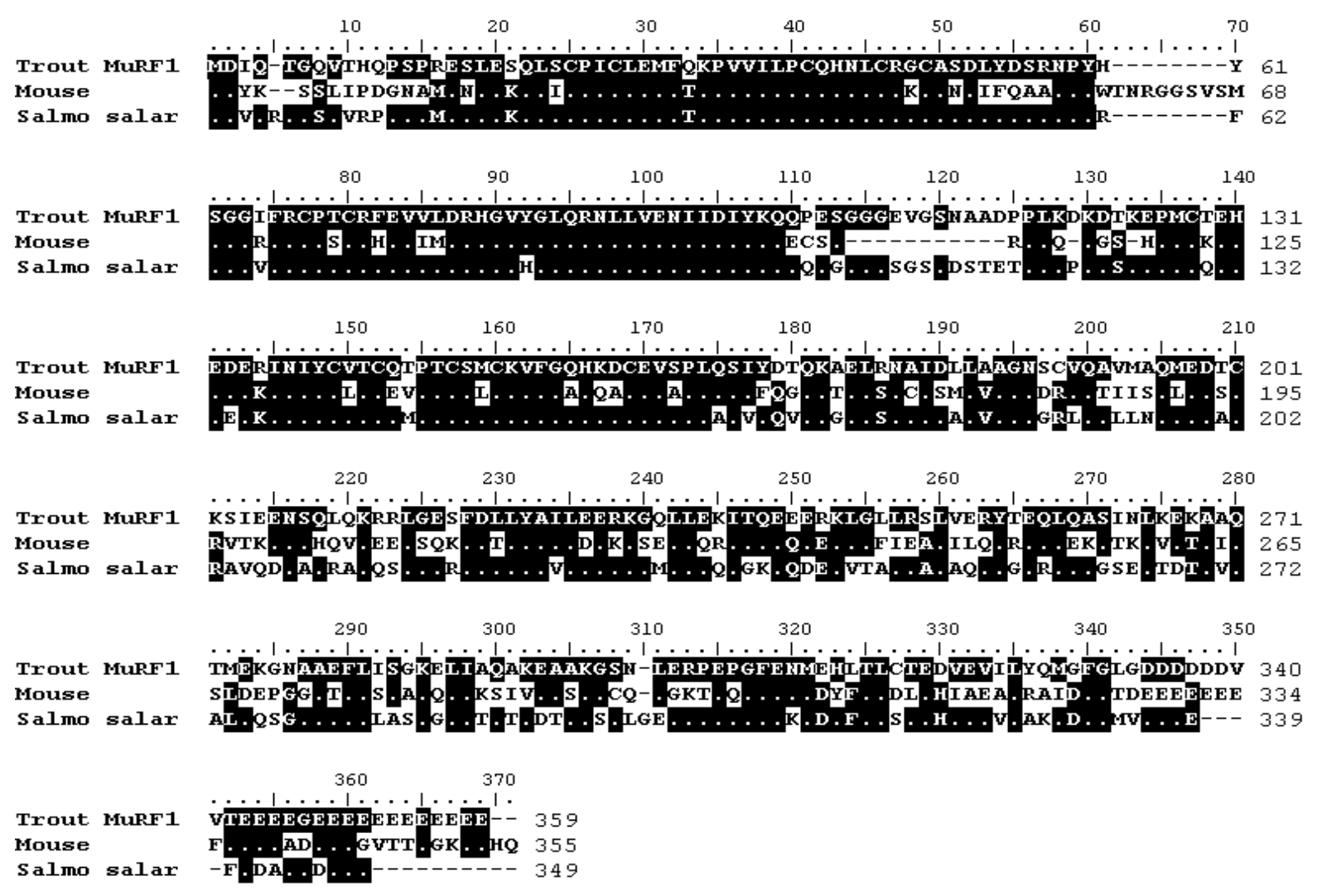

Figure 3: Comparison of the deduced amino acid sequences of rainbow trout MuRF1 with homologous sequences from mouse (NP_001034137.2) and salmon (NP_001133124.1). Identical amino acid residues are shaded in black. The rainbow trout MuRF-1 amino acid sequence shows $67 \%$ identity to Salmon MuRF-1 and 54\% to mouse MuRF-1. 


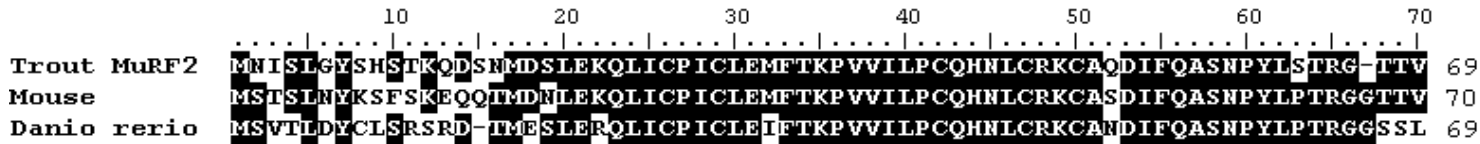

Trout MuRF2

Mouse

90

100

110

120

130

140

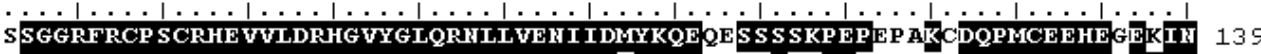
ASGGRFRCP SCRHE UUDDRHG UYGLQRULL UEUI IDTYKOE----STRPEKK---LDQPMCEEHEE BRIY 133

Danio rerio

Trout HupF 2 Mouse

Danio rerio GSGGRFRCP SCRHE TULDRHG WYGLQRULL VEUI I DYYKOE SSSSKPEPQ-VREE VLMCEEHODERIY 136

150 160 $170 \quad 180$ 190 200 210

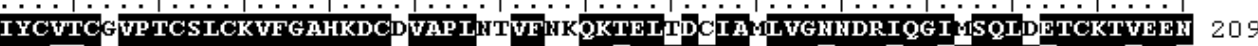

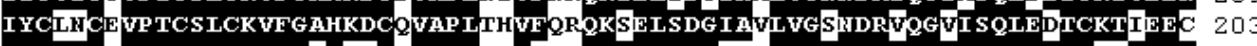

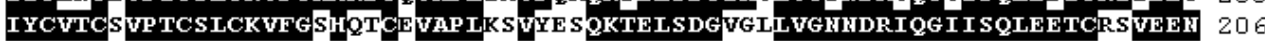

Trout lurf2 Mouse

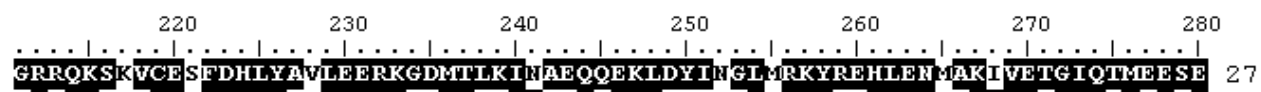

Danio rerio

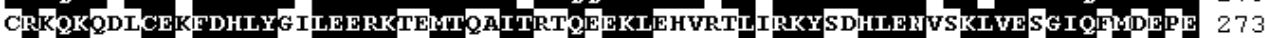

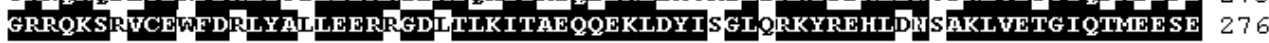

Trout Mupr 2

House

290 300 310 320 330 340 350

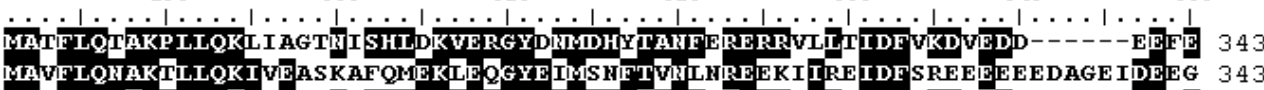

Danio rerio

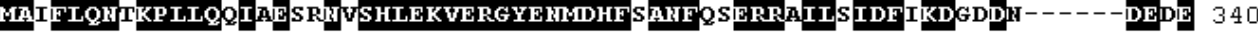
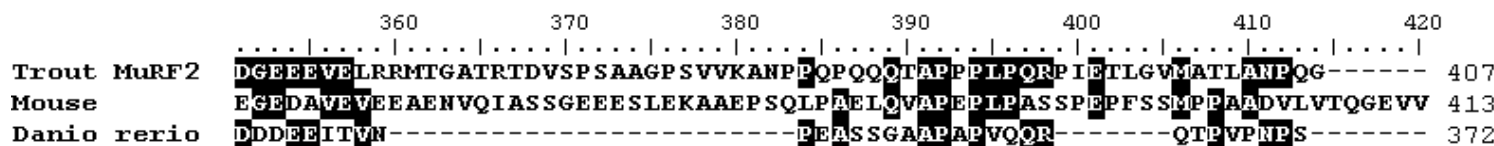

Danio rexio

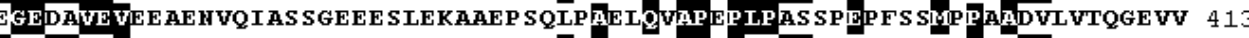
DDDFITHस---

Trout MupF 2 House

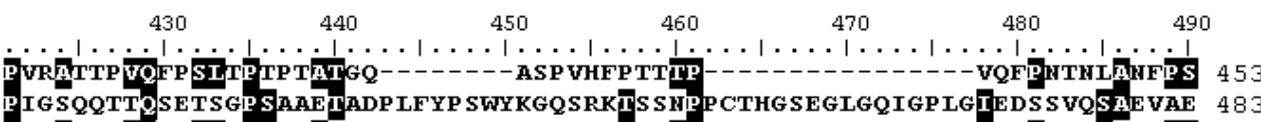

Danio rexio PuAps-trir-SLKP sos IVTPTPDSTHIPS 411

Trout MupF 2 Mouse 500 510 520 530 540 550

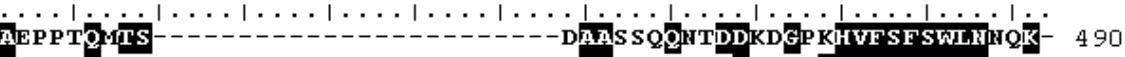

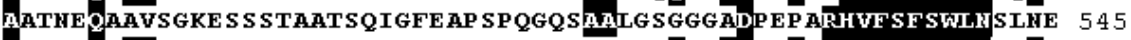

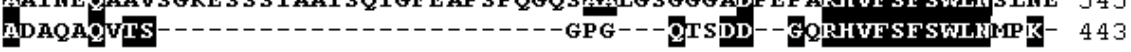

Danio rerio

Figure 4: Comparison of the deduced amino acid sequences of rainbow trout MuRF-2 with homologous sequences from mouse (NP_001074750.1) and zebrafish (NP_001002358.1). Identical amino acid residues are shaded in black. Rainbow trout MuRF-2 shares 59\% sequence identity with zebrafish MuRF2 and 66\% with mouse MuRF2. 


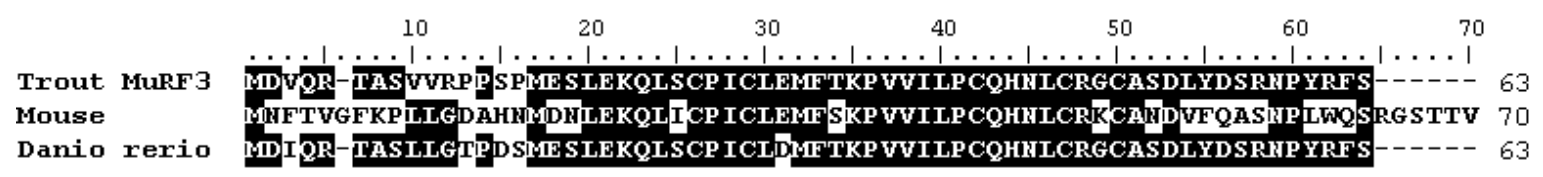

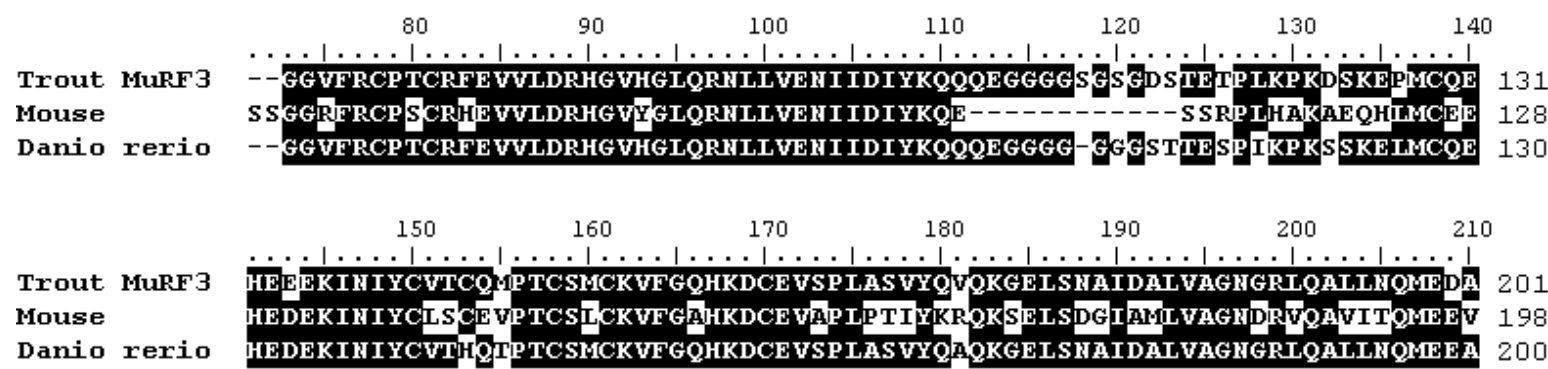

Trout MuRF 3

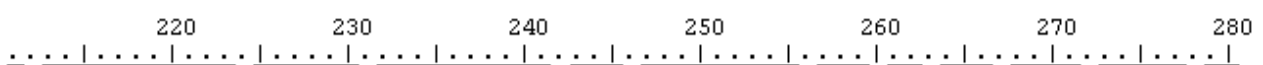

Mouse

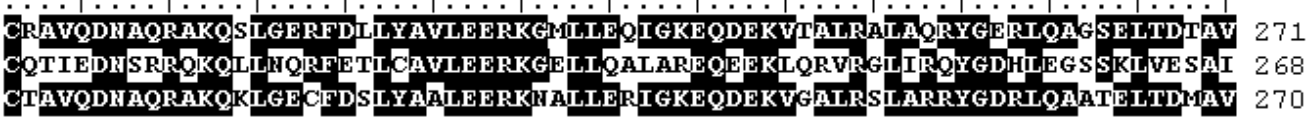

Danio rerio

Trout Mupf 3 Mouse

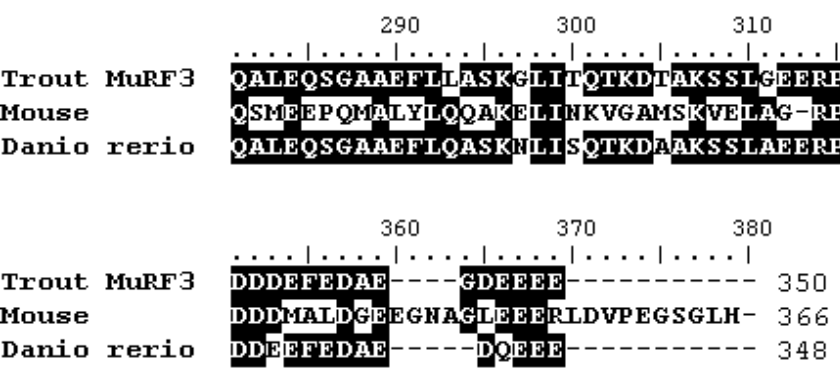

Mouse DDETFEDAE----DQDEE

Danio rerio

Figure 5: Comparison of the deduced amino acid sequences of rainbow trout MuRF-3 with homologous sequences from mouse (NP_067422.1) and zebrafish (CAX15444.1). Identical amino acid residues are shaded in black. The deduced amino acid sequence of rainbow trout MuRF-3 displays high sequence homology with previously reported MuRF-3 proteins in other species (85\% identity to zebrafish and $53 \%$ to mouse MuRF-3). 


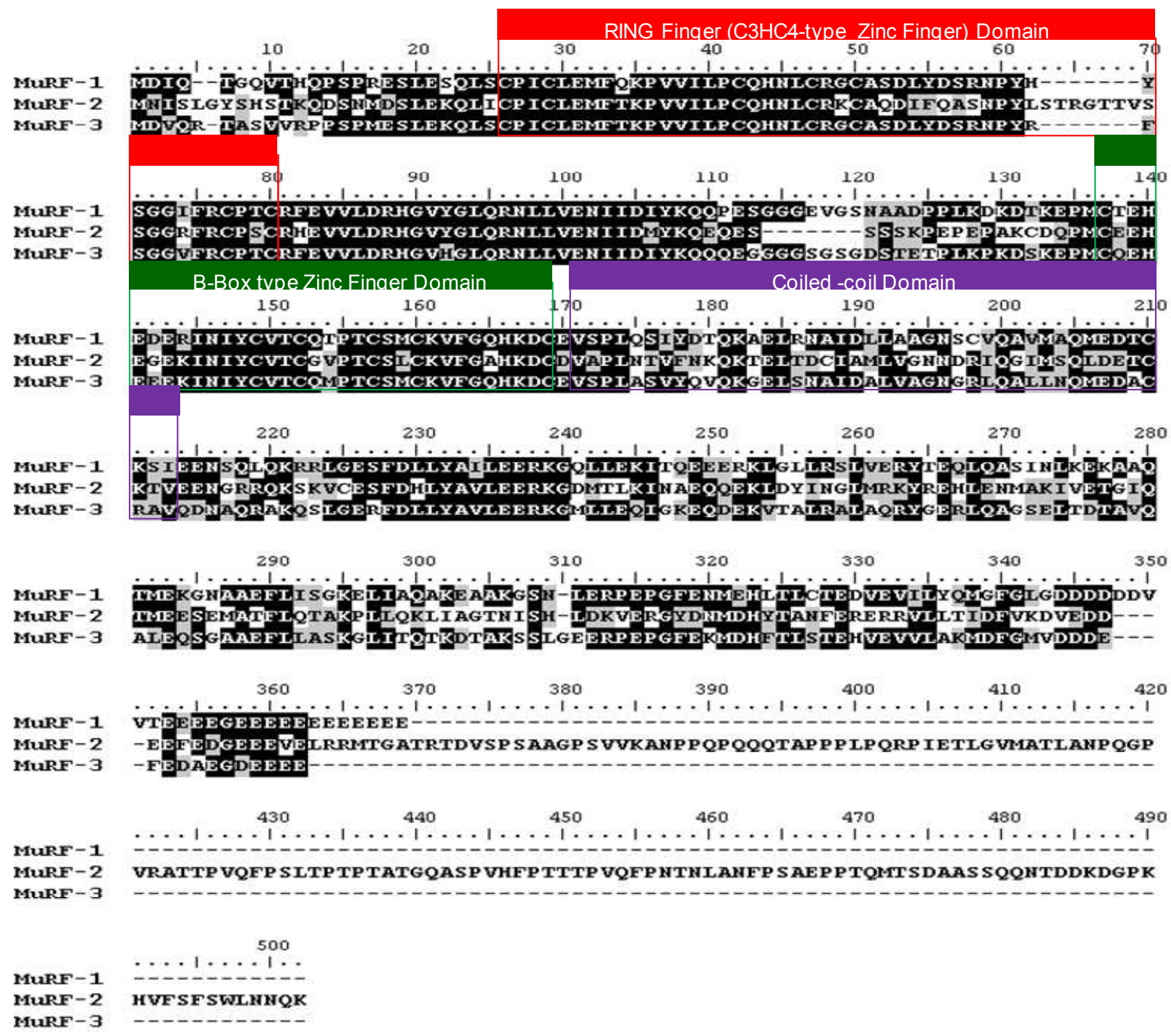

Figure 6: Multiple alignment of the deduced amino acid sequences of rainbow trout MuRF1, MuRF2 and MuRF3 by ClustalW analysis. Identical residues are shaded in black, and conserved substitutions in grey. The following functional domains are indicated: RING-finger domain (Red box), B-box zinc finger domain (Green box) and Leucine-rich coiled-coil domain (Purple box). 


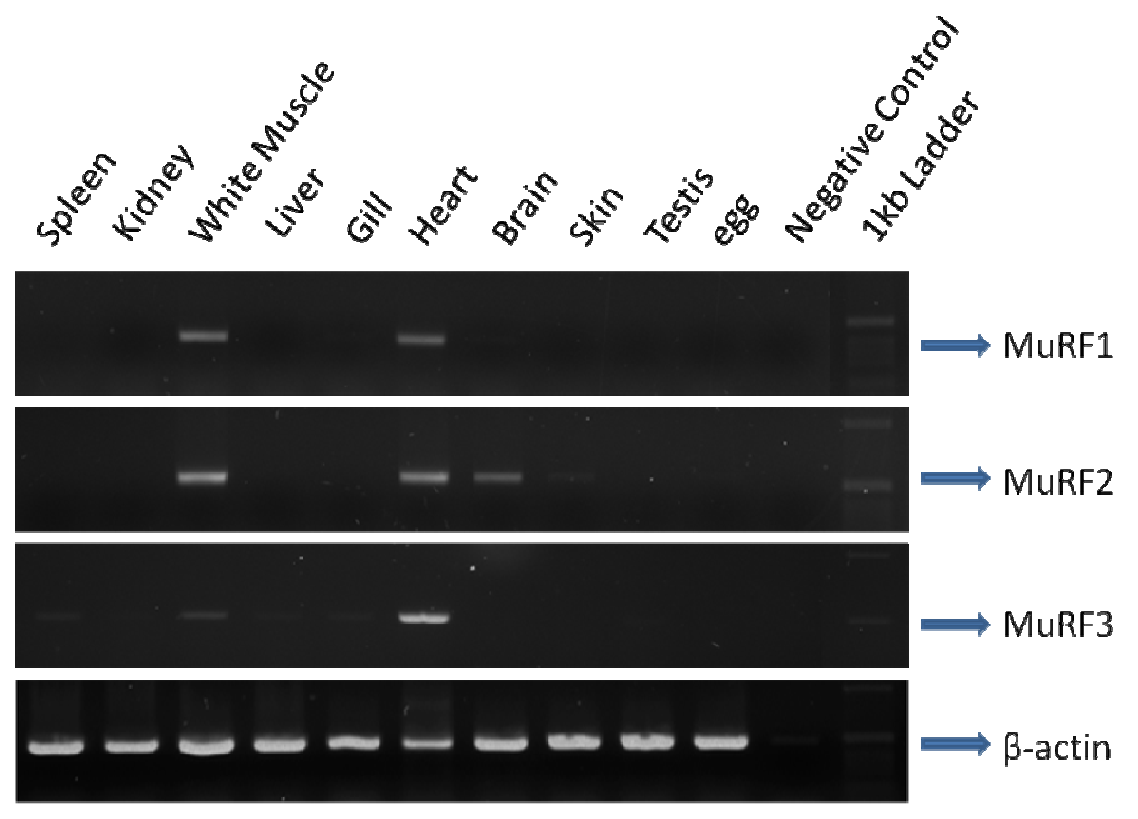

Figure 7: RT-PCR analysis of tissue distribution of the rainbow trout MuRF genes. cDNA from multiple tissues were amplified by PCR using gene specific primers. All three MuRF genes were abundantly expressed in muscle tissue. MuRF-1 appears to be muscle specific as it was only seen in muscle and heart but not in other tissues. MuRF-2 is predominantly expressed in muscle and heart, with lesser amounts in brain. MuRF3 mRNA is also predominantly expressed in muscle and heart, with greater amounts in heart. 


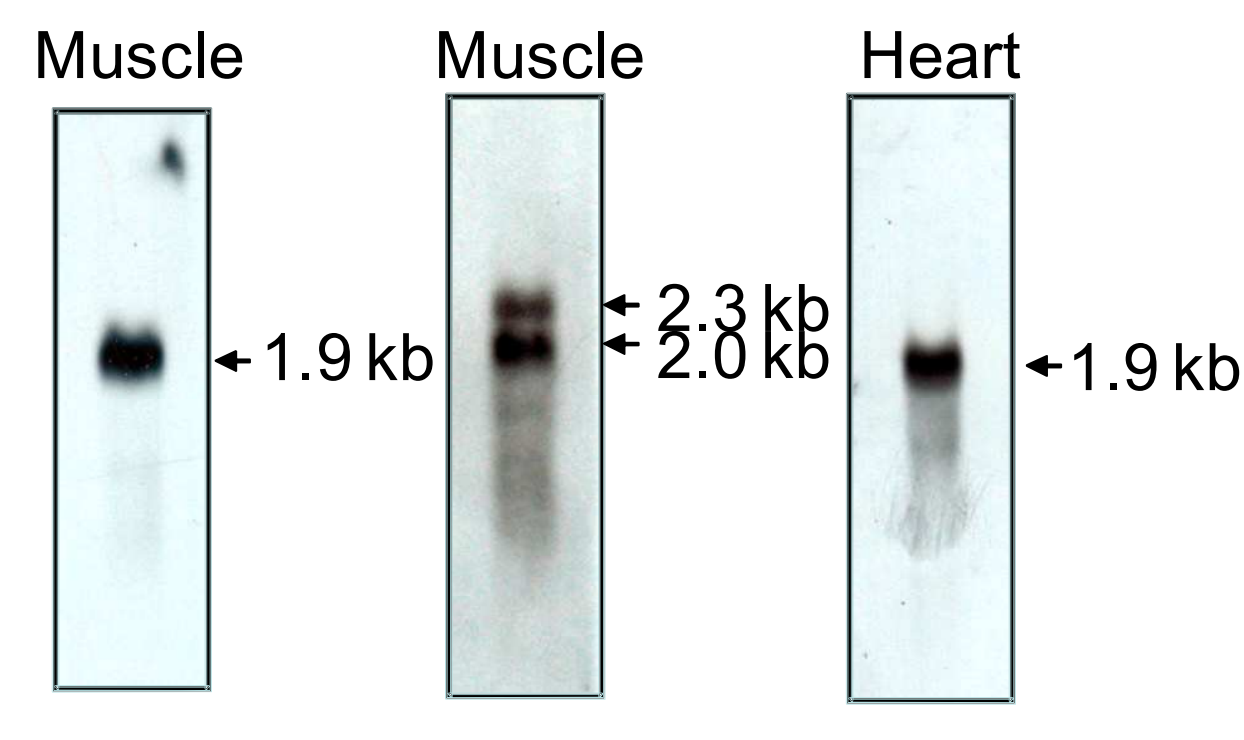

\section{MuRF-1 MuRF-2 MuRF-3}

Figure 8: Northern blot analysis of rainbow trout MuRF transcripts. Messenger RNA isolated muscle/heart was separated on agarose gel and transferred to a nylon membrane before hybridizing to DIG labeled PCR probes for MuRF-1, MuRF-2 and MuRF-3. A single transcript of $1.9 \mathrm{~kb}$ for MuRF-1, 2 transcripts of $2.0 \mathrm{~kb}$ and $2.3 \mathrm{~kb}$ for MuRF-2 and a single transcript of $1.9 \mathrm{~kb}$ for MuRF-3 were detected. 


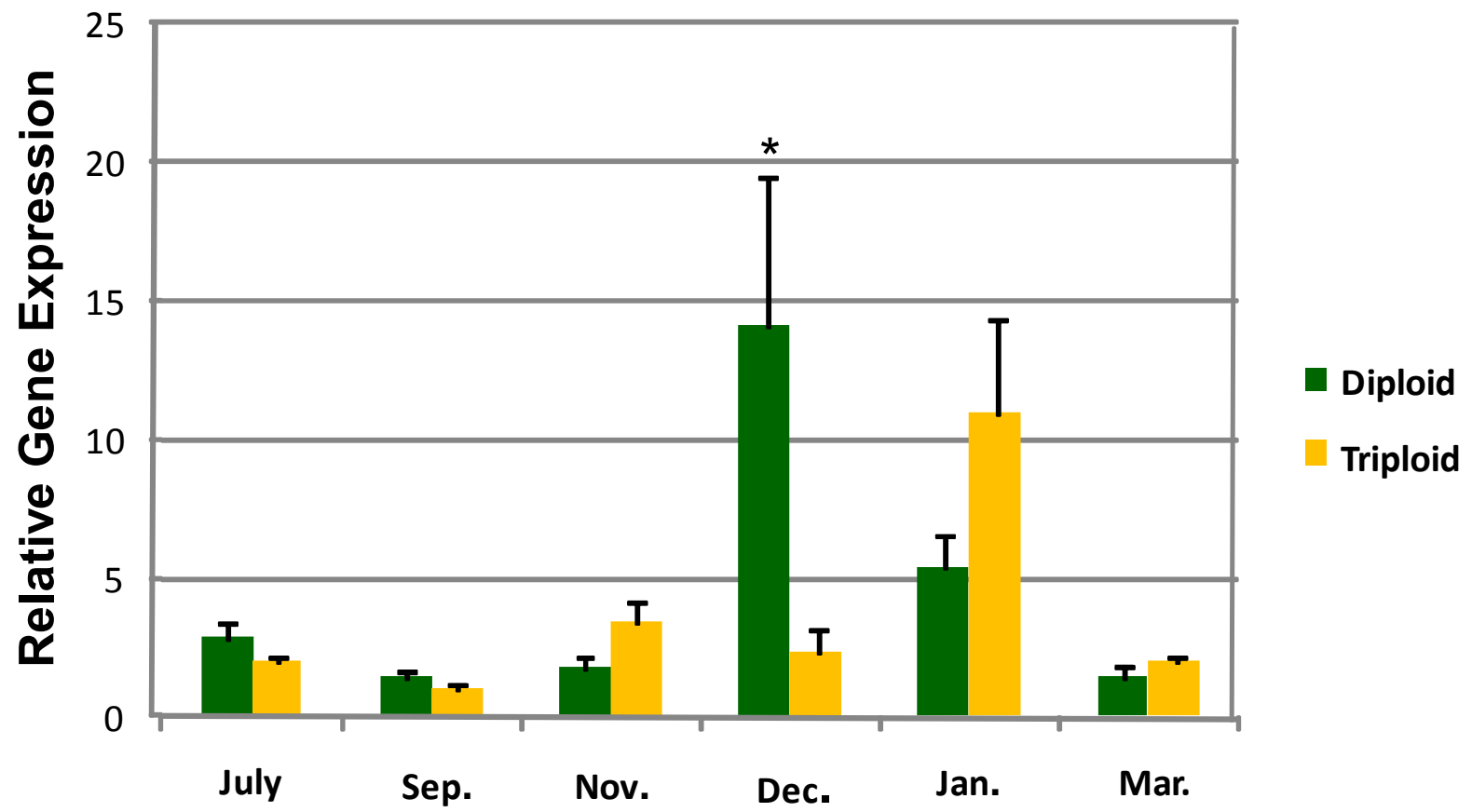

Figure 9. Quantitative analysis of MuRF-1 mRNA expression during sexual maturation by realtime PCR. Six stages of development analyzed include: July, Sep, Nov, Dec, Jan and Mar. The quantity of MuRF-1 mRNA was normalized to trout $\beta$-actin The mean differences in expression levels were determined in each stage between diploid and triploid samples by a t-test. $(\mathrm{n}=7)$ * indicates significant difference $(\mathrm{P}<0.05)$. 


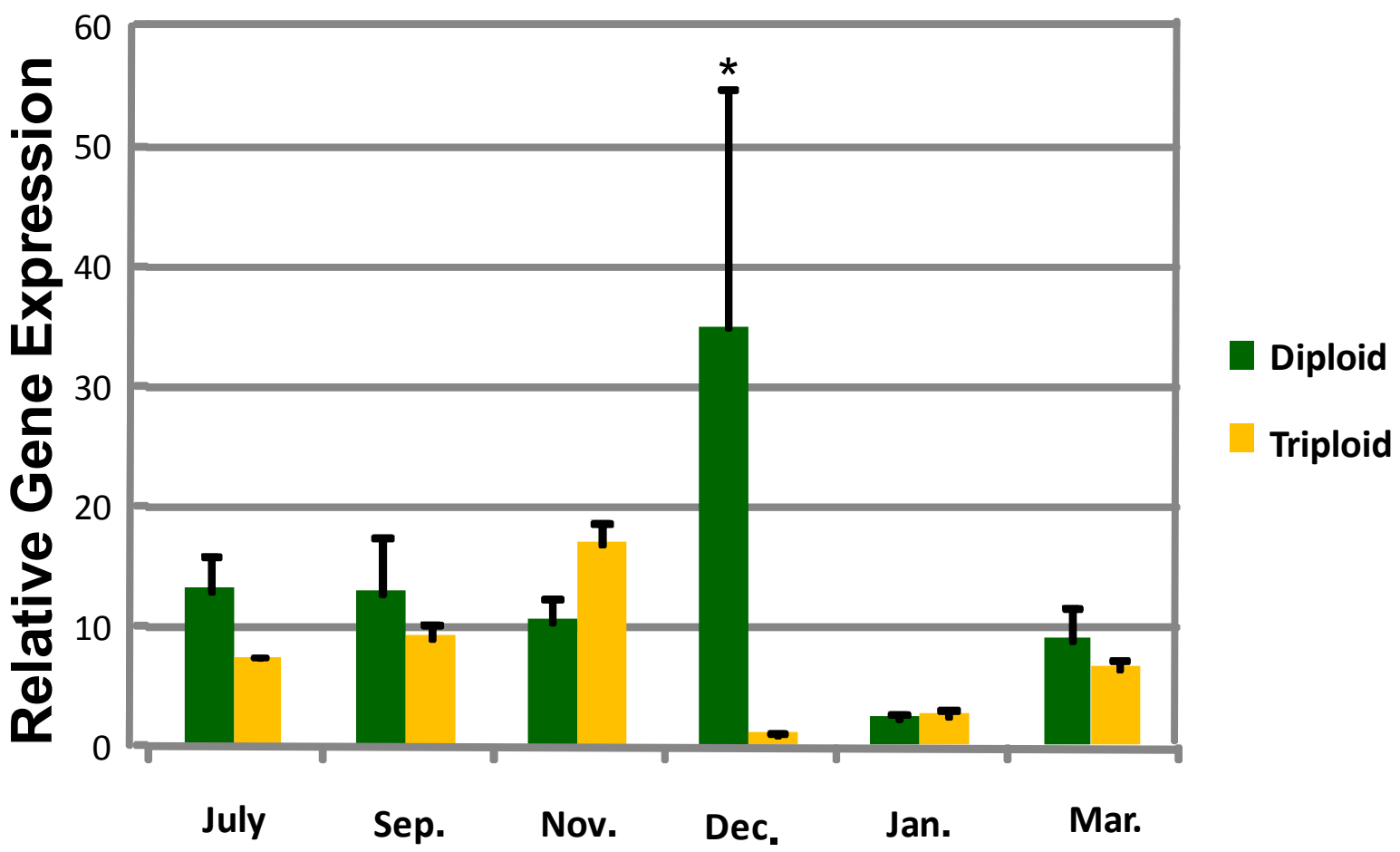

Figure 10. Quantitative analysis of MuRF-2 mRNA expression during sexual maturation by realtime PCR. Six stages of development analyzed include: July, Sep, Nov, Dec, Jan and Mar. The quantity of MuRF-2 mRNA was normalized to trout $\beta$-actin. The mean differences in expression levels were determined in each stage between diploid and triploid samples by a t-test. $(\mathrm{n}=7)$ * indicates significant difference $(\mathrm{P}<0.05)$. 


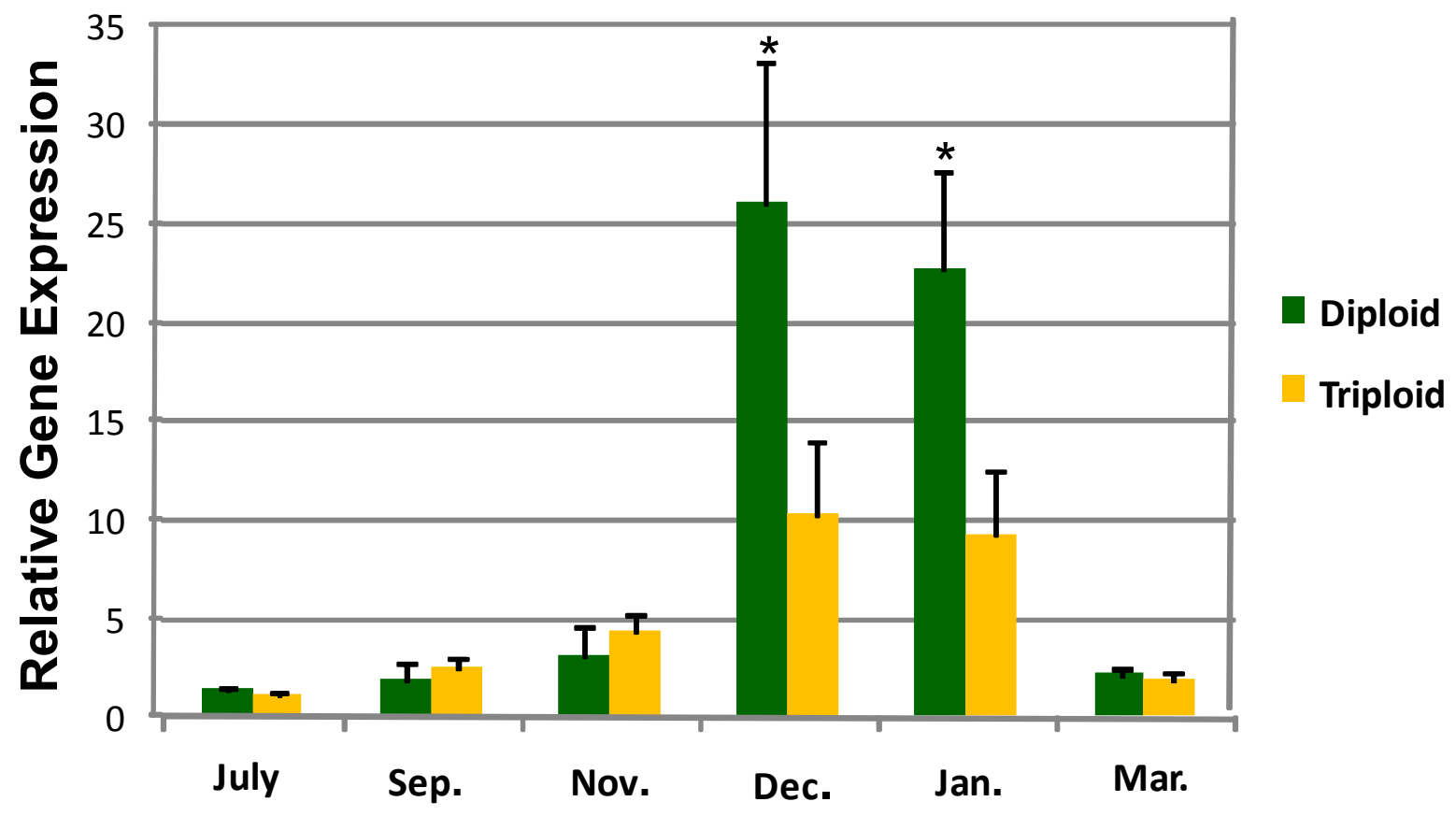

Figure 11. Quantitative analysis of MuRF-3 mRNA expression during sexual maturation by realtime PCR. Six stages of development analyzed include: July, Sep, Nov, Dec, Jan and Mar. The quantity of MuRF-3 mRNA was normalized to trout $\beta$-actin. The mean differences in expression levels were determined in each stage between diploid and triploid samples by a t-test. $(\mathrm{n}=7)$ * indicates significant difference $(\mathrm{P}<0.05)$. 


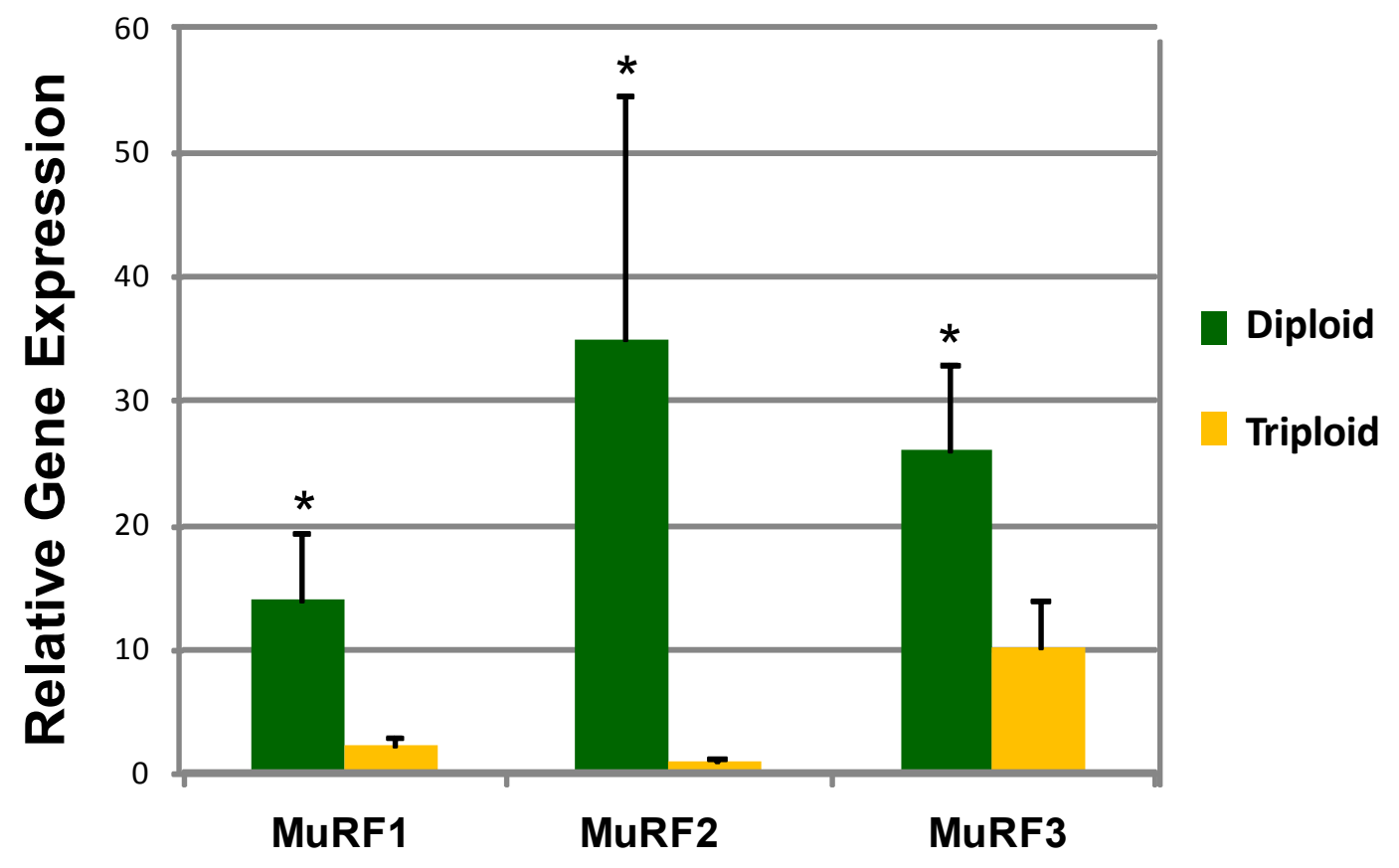

Figure 12. Effect of spawning-induced muscle atrophy on the expression of MuRF genes. Expression of the MuRF genes was analyzed by real-time PCR. Quantity of each MuRF mRNA was normalized to $\beta$-actin. The means of the normalized gene expression values were calculated and expressed as relative fold changes $(n=7$, mean \pm SEM). $*$ indicates significant difference $(\mathrm{P}<0.05)$. 


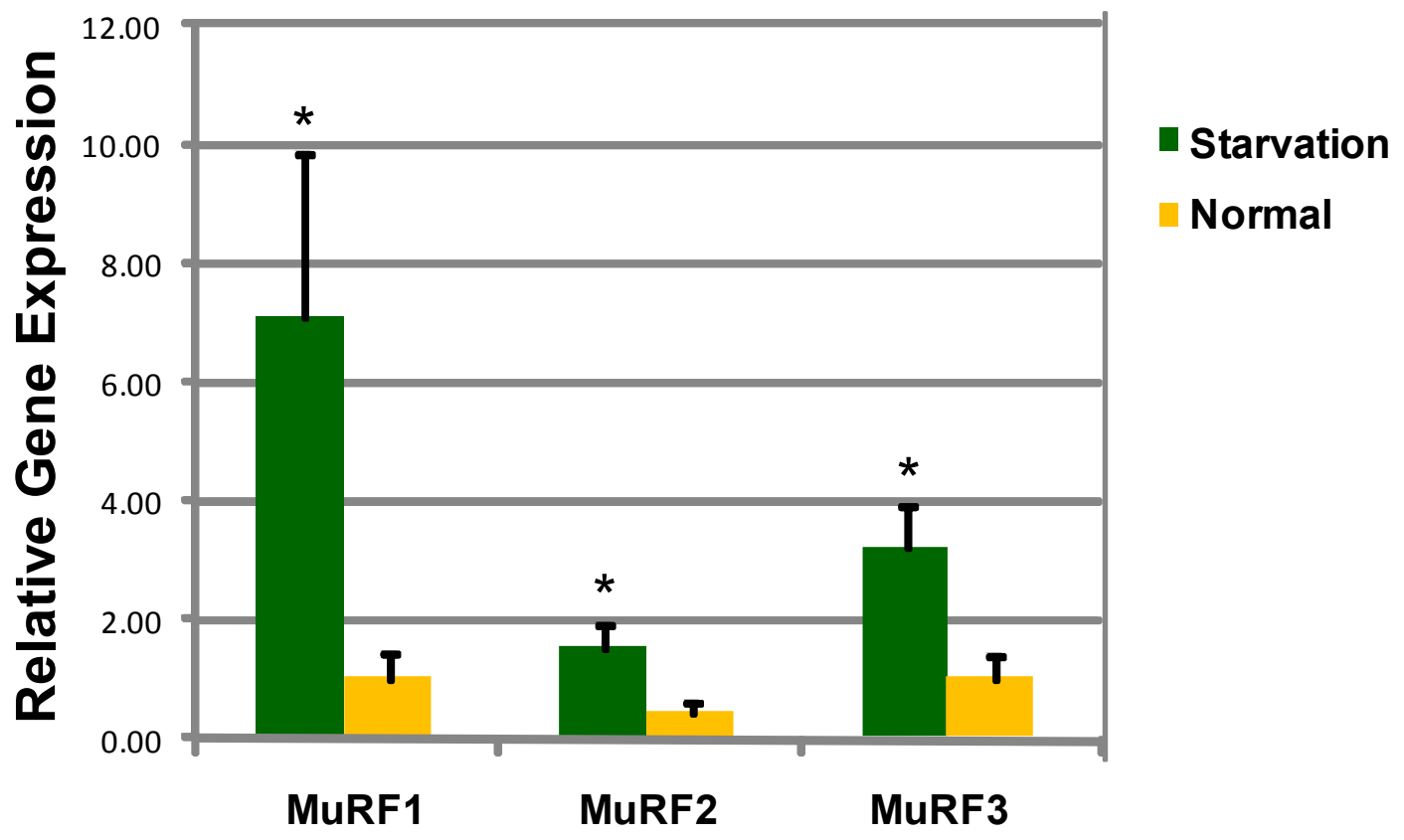

Figure13. Effect of starvation-induced muscle atrophy on the expression of MuRF genes. Expression of the MuRF genes was analyzed by real-time PCR. Quantity of each MuRF mRNA was normalized to $\beta$-actin. The means of the normalized gene expression values were calculated and expressed as relative fold changes $(n=7$, mean \pm SEM $) . *$ indicates significant difference $(\mathrm{P}<0.05)$. 


\section{DISCUSSION}

In this study, we have identified and characterized three full-length cDNA sequences for MuRF genes in rainbow trout. To our knowledge, this is the first report of MuRF genes in nonmammalian animals. The cDNA sequences of these three genes contain complete open reading frames encoding MuRF proteins with characteristic RING-finger, B-box zinc finger and Leucine-rich coiled-coil domains. The RING-finger domain is an unusual type of Cys-His zincbinding motif, with a specialized type of Zn-finger domain containing 40 to 60 residues that bind two atoms of zinc; whereas, the usual zinc finger domains are relatively small protein motifs that binds one or more zinc atoms. It is probably involved in mediating protein-protein interactions, and is identified in proteins with a wide range of functions such as viral replication, signal transduction, gene transcription, differentiation, ubiquitination, morphogenesis and microtubule stabilization. The RING-finger domain has two variants, the C3HC4-type and a C3H2C3-type (RING-H2 finger), that have different cysteine/histidine pattern. The B-box zinc finger domain is also a protein binding domain. The leucine-rich coiled-coil domain mediates association with microtubules. The N-terminal RING finger, B-box and coiled coil domains are abbreviated RBCC. Depending on the RING-finger domain, protein-protein interactions, MuRF-1 is a bona fide RING finger-dependent ubiquitin ligase that catalyzes a rate-limiting step in troponin I degradation. Troponin I is a MuRF-1 interaction partner, and MuRF-1-troponin I interactions can be detected in cardiomyocytes (Kedar, McDonough et al. 2004). We presume that our MuRF proteins, which also contain this RING-finger domain, potentially function to facilitate interaction with other proteins. MuRF is a key component of the ubiquitin ligase complex that is required for protein ubiquitination and degradation. Previously, Salem and coworkers (Salem, Kenney et al. 2006) showed that expression of the ubiquitin-proteasome pathway genes is not 
associated with the vitellogenesis-induced atrophy in rainbow trout. Additionally, Martin and coworkers reported down-regulated expression of proteasome genes in fasting-induced fish muscle degradation (Martin, Blaney et al. 2002). Whereas, we hypothesize that MuRF genes maybe involved in different mechanisms regulating muscle degradation in fish other than the proteasome pathway. Further studies are needed to explain the role of MuRF genes in fish muscle degradation.

The MuRF genes are predominantly expressed in muscle and heart samples, although a weak expression is seen in brain, skin, spleen, liver and gill. In contrast, $\beta$-actin, a housekeeping gene shows ubiquitous expression in all tissues (Fig. 7). Sequence analysis of rainbow trout MuRF-1, MuRF-2 and MuRF-3 demonstrated that they share 49\%-67\% amino acid identity. Comparisons of rainbow trout MuRF proteins with MuRF proteins from other species revealed that rainbow trout MuRF-3 and zebrafish MuRF-3 are highly homologous (85\% sequence identify); whereas, rainbow trout and mouse MuRF-3 share the lowest sequence homology (53\%). Rainbow trout MuRF-1 is 54 and $67 \%$ identical to mouse and salmon MuRF-1, respectively; whereas, MuRF-2 is 66 and 59\% identical to mouse and zebrafish MuRF-2, respectively. This not only suggests that rainbow trout MuRF genes are evolutionarily conserved, but it also suggests conserved functionality such as enzymatic activities.

To determine transcript sizes and splice variants of three MuRF genes, Northern blot analysis was performed on muscle and heart tissues. The analysis clearly detected transcript sizes that are expected based on the cDNA sequences, indicating that cDNA sequences are full-length. A single band was detected for MuRF-1 and MuRF-3 transcripts, but two bands were detected for MuRF-2. The smaller band of approximately $2.0 \mathrm{~kb}$ may represent a splice variant. 
Muscle atrophy refers to wasting of muscle tissue resulting from conditions such as starvation or systemic diseases (cancer, diabetes, sepsis). During fish spawning, muscle atrophy is a physiological response to the increased energetic demands; starvation also induces muscle atrophy (Salem, Kenney et al. 2006). These responses represent suitable models to study mechanisms of muscle degradation/ regeneration in fish.

During the sexual maturation, vitellogenin, an egg yolk precursor protein expressed in female fish, is synthesized under estrogen control in the liver, extensively modified, and transported to the ovary before processing to yolk proteins (lipovitellin and phosvitin). Uptake of vitellogenin into oocytes triggers vitellogenesis (Emmersen and Emmersen 1976; van Bohemen, Lambert et al. 1981; Vaillant, Le Guellec et al. 1988). Vitellogenesis, also known as yolk deposition, is the process of yolk formation via nutrients being deposited in the oocyte, or female germ cell. Since, in oviparous and ovoviviparous fishes, there is no link between the mother and the developing embryo, eggs must be prepackaged with yolk deposits so that energy and nutrients (amino acids)can be derived from the breakdown of vitellogenin during embryogenesis. The reproductive cycle (gonad development) can be divided into the following phases (Fig.14): (1) The preparatory phase marks the beginning of the reproductive cycle and during this phase the gonad weight is low and starts to increase. (2) During the prespawning phase, gonad weight increases significantly, and fishes are ready to undergo the process of fertilization and spawning. (3) During the spawning phase, the fish exhibit mating behavior and undergo fertilization. (4) Lastly, during the post spawning phase there is marked by decrease in gonad weight due to release of eggs from the ovaries for fertilization. 


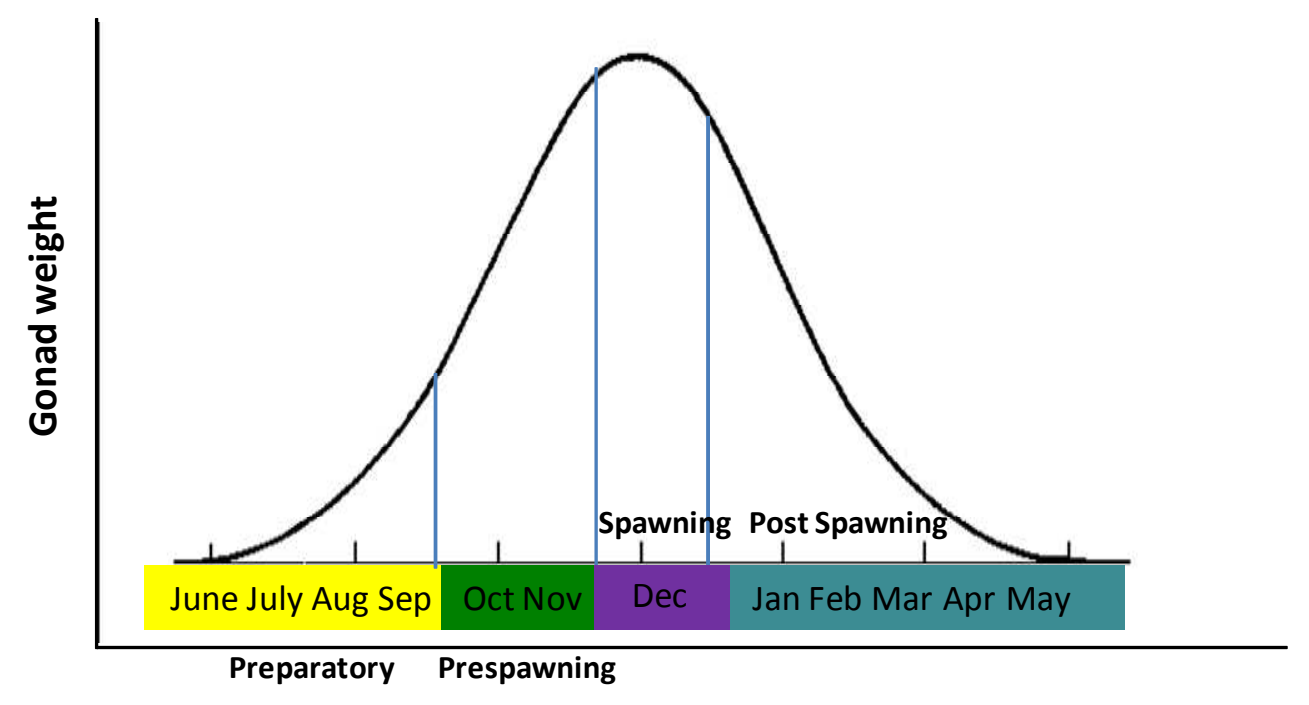

Fig.14 Generalized annual gonadal cycle of freshwater fish

During the spawning phase, white muscle acts as the major energy source once lipids are depleted (Love 1979; Mommsen, Ballantyne et al. 1981; Ando, Ito et al. 1998; Mommsen 2004). (Martin, Houlihan et al. 1993 ) reported a decrease in body mass of $10 \%$ and $15 \%$ in sexually maturing male and female salmon, respectively. White muscle declined in mass, and net protein losses occurred in all tissues except the ovary. The ovary shows an $82 \%$ increase in protein synthesis, resulting in a tenfold increase in protein mass (Martin, Houlihan et al. 1993 ). The clear and dramatic increase in weight and protein content of gonadal tissues, particularly the ovary occurred largely at the expense of white muscle which, before the onset of sexual maturity, contained more than $50 \%$ of the body protein. By spawning time, $54 \%$ was lost (McMillan and Houlihan 1992). MuRF1, MuRF2 and MuRF3 genes showed low and steady expression during July, Sep and Nov in $2 \mathrm{~N}$ and $3 \mathrm{~N}$ fish muscle (Fig. 9, 10, 11). In this preparatory phase, the gonad just starts to increase in weight. All MuRF genes showed significantly $(\mathrm{P}<0.05)$ increased expression in $2 \mathrm{~N}$ fishes in Dec. (Fig.12), one month before spawning. Muscle acts as a major energy source to support energy demanding vitellogenesis. Increased MuRF gene expression is 
consistent with elevated protein degradation. Following spawning, during Jan-Mar, MuRF genes showed normal expression in 2N fish. This expression pattern suggests a role for MuRF genes in the initial phases of muscle protein mobilization. MuRFs are Ub-protein ligases (E3) which are key players in the regulation of ubiquitin-proteasome-mediated, muscle atrophy in mammals (Bodine, Latres et al. 2001; Gomes, Lecker et al. 2001; Lecker, Jagoe et al. 2004). In our study, rainbow trout MuRF expression was up-regulated, accompanying muscle protein degradation and suggesting an important role of MuRFs in spawning-induced muscle atrophy. But their role in proteolysis is still unknown.

Starvation triggers up-regulated MuRF gene expression. In addition, MuRF genes showed higher expression in starved fish than in normal fish (Fig. 13). Real time PCR demonstrated a 7.1-fold increase in mRNA abundance of MuRF-1, a 1.5-fold increase of MuRF2, and a 2.8-fold increase of MuRF-3 $(\mathrm{P}<0.05)$ in fish that have had food withdrawn for 35 days compared to fed controls. In starved rainbow trout and cod, tissues with high protein synthesis rates, such as the gill, liver and intestine, showed rapid increases in protein synthesis rates after a single meal, with measured rates comparable to those seen in continually feeding animals (Lyndon, Houlihan et al. 1992; McMillan and Houlihan 1992). In contrast, tissues with generally lower protein synthesis rates, such as white skeletal muscle and cardiac muscle, had slower increases in protein synthesis rates that did not reach levels seen in continually fed fish (Lyndon, Houlihan et al. 1992; McMillan and Houlihan 1992). White muscle appears very sensitive to starvation, with protein synthesis rates decreasing rapidly when feeding ceases (Smith and Haschemeyer 1980; Haschemeyer 1983; Pocrnjic, Mathews et al. 1983; Fauconneau and Arnal 1985; Houlihan, Agnisola et al. 1988). The sensitivity of white muscle protein synthesis is particularly important to overall growth, any decrease in white muscle protein synthesis will 
have a substantial effect on both growth and metabolism (Houlihan, Agnisola et al. 1988). The observed decrease in white muscle protein synthesis during starvation appears to be highly protein specific, with a $90 \%$ decrease in myofibrillar protein synthesis observed during starvation in Paralabrax nebulifer (Lowery and Somero 1990).

Considerably less is understood about the effects of starvation on protein degradation. Nonetheless, (Martin, Blaney et al. 2002) demonstrated that activity of the proteasome pathway, a major mechanism of protein degradation, is reduced after 2 weeks starvation in rainbow trout. In contrast, lysosomal enzyme activity appears to increase during starvation (Martin, del Pozo et al. 2000). Additionally, (Dobly, Martin et al. 2004) reported a negative correlation between trout liver, but not white muscle, $20 \mathrm{~S}$ proteasome activity and specific growth rate.

In summary, we identified cDNA sequences for rainbow trout MuRF-1, MuRF-2, and MuRF-3 genes. These genes are predominantly expressed in muscle and heart tissues, and they encode proteins with characteristic MuRF structural domains. Expression of these genes was upregulated in starvation- and spawning-induced muscle atrophy conditions in rainbow trout, suggesting important roles in muscle protein degradation.

In future studies, it is necessary to determine the mechanisms of MuRF genes in regulation of muscle degradation in fish. Further investigations are required to evaluate the potential use of MuRF genes as genetic markers for muscle growth and fillet firmness traits in trout. 


\section{LITERATURE CITED}

Ando, K., Y. Ito, et al. (1998). "Oxidative stress increases adrenomedullin mRNA levels in cultured rat vascular smooth muscle cells." Hypertens Res 21(3): 187-91.

Anonymous (1994). "United States Department of Commerce, National Marine Fisheries Service. Fisheries of the United States, 1993, Current Fishery Statistics No. 9300. Washington, D.C."

Anonymous (1995). "Status of world aquaculture 1994. Aquaculture Magazine Buyer's Guide'95. v. 24, pp. 8-23."

Anonymous (1995). "United States Department of Commerce, Bureau of Census. 1992 Census of Agriculture: Geographic Area Series, Vol. 1. Washington, D.C. ."

Attaix, D., L. Combaret, et al. (2001). "Regulation of proteolysis." Curr Opin Clin Nutr Metab Care 4(1): 45-9.

Attaix, D., S. Ventadour, et al. (2005). "The ubiquitin-proteasome system and skeletal muscle wasting." Essays Biochem 41: 173-86.

Bartoli, M. and I. Richard (2005). "Calpains in muscle wasting." Int J Biochem Cell Biol 37(10): 2115-33.

Bodine, S. C., E. Latres, et al. (2001). "Identification of ubiquitin ligases required for skeletal muscle atrophy." Science 294(5547): 1704-8.

Borden, K. L. (1998). "RING fingers and B-boxes: zinc-binding protein-protein interaction domains." Biochem Cell Biol 76(2-3): 351-8.

Busquets, S., C. Garcia-Martinez, et al. (2006). "Overexpression of UCP3 in both murine and human myotubes is linked with the activation of proteolytic systems: a role in muscle wasting?" Biochim Biophys Acta 1760(2): 253-8.

Cao, J. L., J. H. He, et al. (2005). "Activation of the spinal ERK signaling pathway contributes naloxone-precipitated withdrawal in morphine-dependent rats." Pain 118(3): 336-49.

Carter, C. G. and M. P. Bransden (2001). "Relationships between protein-nitrogen flux and feeding regime in greenback flounder, Rhombosolea tapirina (Gunther)." Comp Biochem Physiol A Mol Integr Physiol 130(4): 799-807.

Costelli, P., M. Muscaritoli, et al. (2005). "Skeletal muscle wasting in tumor-bearing rats is associated with MyoD down-regulation." Int J Oncol 26(6): 1663-8.

Dobly, A., S. A. Martin, et al. (2004). "Protein growth rate in rainbow trout (Oncorhynchus mykiss) is negatively correlated to liver 20S proteasome activity." Comp Biochem Physiol A Mol Integr Physiol 137(1): 75-85.

Emmersen, B. K. and J. Emmersen (1976). "Protein, RNA, and DNA metabolism in relation to ovarian vitellogenic growth in the flounder Platichthys flesus (L.)." Comp Biochem Physiol B 55(2): 315-21.

Farges, M. C., D. Balcerzak, et al. (2002). "Increased muscle proteolysis after local trauma mainly reflects macrophage-associated lysosomal proteolysis." Am J Physiol Endocrinol Metab 282(2): E326-35.

Fauconneau, B. and M. Arnal (1985). "In vivo protein synthesis in different tissues and the whole body of rainbow trout (Salmo gairdnerii R.). Influence of environmental temperature." Comp Biochem Physiol A Comp Physiol 82(1): 179-87.

Fielitz, J., E. van Rooij, et al. (2007). "Loss of muscle-specific RING-finger 3 predisposes the heart to cardiac rupture after myocardial infarction." Proc Natl Acad Sci U S A 104(11): 4377-82. 
Freemont, P. S. (2000). "RING for destruction?" Curr Biol 10(2): R84-7.

Gomes, M. D., S. H. Lecker, et al. (2001). "Atrogin-1, a muscle-specific F-box protein highly expressed during muscle atrophy." Proc Natl Acad Sci U S A 98(25): 14440-5.

Haschemeyer, A. E. (1983). "A comparative study of protein synthesis in nototheniids and icefish at Palmer Station, Antarctica." Comp Biochem Physiol B 76(3): 541-3.

Hasselgren, P. O., M. J. Menconi, et al. (2005). "Novel aspects on the regulation of muscle wasting in sepsis." Int J Biochem Cell Biol 37(10): 2156-68.

Hershko, A., A. Ciechanover, et al. (2000). "Basic Medical Research Award. The ubiquitin system." Nat Med 6(10): 1073-81.

Hopkins, T. A. and W. E. Manci (1992). "Aquaculture: Opportunity Now Part 1. Aqua. Mag. Nov/Dec 1992, pp. 43-47. ."

Houlihan, D. F., C. Agnisola, et al. (1988). "Protein synthesis in a fish heart: responses to increased power output." J Exp Biol 137: 565-87.

Houlihan, W. J., P. G. Munder, et al. (1995). "Preclinical pharmacology and possible mechanism of action of the novel antitumor agent 5-(4'-piperidinomethylphenyl)-2,3-dihydroimidazo [2,1-a]isoquinoline." Arzneimittelforschung 45(10): 1133-7.

Jagoe, R. T. and A. L. Goldberg (2001). "What do we really know about the ubiquitinproteasome pathway in muscle atrophy?" Curr Opin Clin Nutr Metab Care 4(3): 183-90.

Kedar, V., H. McDonough, et al. (2004). "Muscle-specific RING finger 1 is a bona fide ubiquitin ligase that degrades cardiac troponin I." Proc Natl Acad Sci U S A 101(52): 18135-40.

Kettelhut, I. C., S. S. Wing, et al. (1988). "Endocrine regulation of protein breakdown in skeletal muscle." Diabetes Metab Rev 4(8): 751-72.

Kumamoto, T., S. Fujimoto, et al. (2000). "Proteasome expression in the skeletal muscles of patients with muscular dystrophy." Acta Neuropathol 100(6): 595-602.

Lecker, S. H., A. L. Goldberg, et al. (2006). "Protein degradation by the ubiquitin-proteasome pathway in normal and disease states." J Am Soc Nephrol 17(7): 1807-19.

Lecker, S. H., R. T. Jagoe, et al. (2004). "Multiple types of skeletal muscle atrophy involve a common program of changes in gene expression." FASEB J 18(1): 39-51.

Lecker, S. H., V. Solomon, et al. (1999). "Muscle protein breakdown and the critical role of the ubiquitin-proteasome pathway in normal and disease states." J Nutr 129(1S Suppl): 227S$237 \mathrm{~S}$.

Lee, Y. J., C. J. Froelich, et al. (2004). "Reconstitution of caspase-3 confers low glucoseenhanced tumor necrosis factor-related apoptosis-inducing ligand cytotoxicity and Akt cleavage." Clin Cancer Res 10(6): 1894-900.

Leeuwenburgh, C., C. M. Gurley, et al. (2005). "Age-related differences in apoptosis with disuse atrophy in soleus muscle." Am J Physiol Regul Integr Comp Physiol 288(5): R1288-96.

Love, R. M. (1979). "The post-mortem $\mathrm{pH}$ of cod and haddock muscle and its seasonal variation." J Sci Food Agric 30(4): 433-8.

Lowery, M. S. and G. N. Somero (1990). "Starvation effects on protein synthesis in red and white muscle of the barred sand bass, Paralabras nebulifer. ." Physiol. Zool. 63: 630-648.

Lynch, G. S., J. D. Schertzer, et al. (2007). "Therapeutic approaches for muscle wasting disorders." Pharmacol Ther 113(3): 461-87.

Lyndon, A. R., D. F. Houlihan, et al. (1992). "The effect of short-term fasting and a single meal on protein synthesis and oxygen consumption in cod, Gadus morhua." J Comp Physiol B 162(3): 209-15. 
Martin, A. C., J. C. del Pozo, et al. (2000). "Influence of cytokinins on the expression of phosphate starvation responsive genes in Arabidopsis." Plant J 24(5): 559-67.

Martin, N. B., D. F. Houlihan, et al. (1993 ). "Protein metabolism during sexual maturation in female Atlantic salmon (Salmo salar L)." Fish Physiology and Biochemistry 12(Number 2 / August, 1993): 131-141.

Martin, S. A., S. Blaney, et al. (2002). "Ubiquitin-proteasome-dependent proteolysis in rainbow trout (Oncorhynchus mykiss): effect of food deprivation." Pflugers Arch 445(2): 257-66.

McCarthy, T. L., S. Casinghino, et al. (1994). "Complex pattern of insulin-like growth factor binding protein expression in primary rat osteoblast enriched cultures: regulation by prostaglandin E2, growth hormone, and the insulin-like growth factors." J Cell Physiol 160(1): 163-75.

McElhinny, A. S., K. Kakinuma, et al. (2002). "Muscle-specific RING finger-1 interacts with titin to regulate sarcomeric M-line and thick filament structure and may have nuclear functions via its interaction with glucocorticoid modulatory element binding protein-1." $\underline{\mathrm{J}}$ Cell Biol 157(1): 125-36.

McMillan, D. N. and D. F. Houlihan (1992). "Protein synthesis in trout liver is stimulated by both feeding and fasting." Fish Physiology and Biochemistry 10(Number 1 / May, 1992): 23-34.

Millward, D. J. (1985). "The physiological regulation of proteolysis in muscle." Biochem Soc Trans 13(6): 1023-6.

Mitch, W. E. (1996). "Metabolic acidosis stimulates protein metabolism in uremia." Miner Electrolyte Metab 22(1-3): 62-5.

Mommsen, T. P. (2004). "Salmon spawning migration and muscle protein metabolism: the August Krogh principle at work." Comp Biochem Physiol B Biochem Mol Biol 139(3): 383-400.

Mommsen, T. P., J. Ballantyne, et al. (1981). "Analogues of red and white muscle in squid mantle." Proc Natl Acad Sci U S A 78(5): 3274-3278.

NAHMS (1995). "NAHMS (National Animal Health Monitoring System), Overview of aquaculture in the United States. (http://www.aphis.usda.gov/vs/ceah/cahm/Aquaculture/aqua.htm ".

Pickart, C. M. (2001). "Mechanisms underlying ubiquitination." Annu Rev Biochem 70: 503-33.

Pocrnjic, Z., R. W. Mathews, et al. (1983). "Quantitative protein synthetic rates in various tissues of a temperate fish in vivo by the method of phenylalanine swamping." Comp Biochem Physiol B 74(4): 735-8.

Roberts, S. J., M. S. Lowery, et al. (1988). "Regulation of binding of phosphofructokinase to myofibrils in the red and white muscle of the barred sand bass, Paralabrax nebulifer (Serranidae)." J Exp Biol 137: 13-27.

Salem, M., P. B. Kenney, et al. (2006). "Microarray gene expression analysis in atrophying rainbow trout muscle: a unique nonmammalian muscle degradation model." Physiol Genomics 28(1): 33-45.

Salem, M., J. Yao, et al. (2005). "Characterization of calpastatin gene in fish: its potential role in muscle growth and fillet quality." Comp Biochem Physiol B Biochem Mol Biol 141(4): 488-97.

Saurin, A. J., K. L. Borden, et al. (1996). "Does this have a familiar RING?" Trends Biochem Sci 21(6): 208-14. 
Siu, P. M. and S. E. Alway (2006). "Deficiency of the Bax gene attenuates denervation-induced apoptosis." Apoptosis 11(6): 967-81.

Smith, M. A. K. and A. E. V. Haschemeyer (1980). "Protein metabolism and cold adaptation in Antarctic fishes." Physiol. Zool. 53: 373-382.

Spencer, J. A., S. Eliazer, et al. (2000). "Regulation of microtubule dynamics and myogenic differentiation by MURF, a striated muscle RING-finger protein." J Cell Biol 150(4): 771-84.

Tews, D. S., W. Behrhof, et al. (2005). "Expression patterns of initiator and effector caspases in denervated human skeletal muscle." Muscle Nerve 31(2): 175-81.

Thorgaard, G. H., G. S. Bailey, et al. (2002). "Status and opportunities for genomics research with rainbow trout." Comp Biochem Physiol B Biochem Mol Biol 133(4): 609-46.

Tisdale, M. J. (2005). "The ubiquitin-proteasome pathway as a therapeutic target for muscle wasting." J Support Oncol 3(3): 209-17.

Tripathi, G. and P. Verma (2003). "Starvation-induced impairment of metabolism in a freshwater catfish." Z Naturforsch C 58(5-6): 446-51.

Vaillant, C., C. Le Guellec, et al. (1988). "Vitellogenin gene expression in primary culture of male rainbow trout hepatocytes." Gen Comp Endocrinol 70(2): 284-90.

van Bohemen, C. G., J. G. Lambert, et al. (1981). "Annual changes in plasma and liver in relation to vitellogenesis in the female rainbow trout, Salmo gairdneri." Gen Comp Endocrinol 44(1): 94-107. 